\title{
QUANTIFYING THE ECOLOGICAL VALUES OF LAND USE TYPES VIA CRITERIA-BASED FARMERS' ASSESSMENT AND EMPIRICALLY ANALYZED SOIL PROPERTIES IN SOUTHERN ETHIOPIA
}

\author{
Ketema, H. ${ }^{1,2}-\mathrm{WU}, \mathrm{W} .{ }^{1,3^{*}}-$ TEMESGEN, $\mathrm{H}^{1,2}$

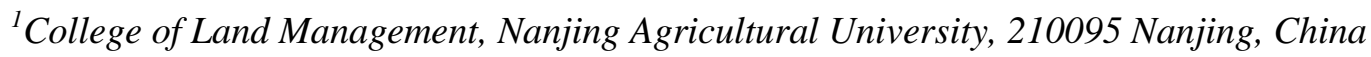 \\ (e-mail: haileketema2005@yahoo.com) \\ ${ }^{2}$ Department of Natural Resource Management, College of Agriculture and Natural Resources, \\ Dilla University, 419 Dilla, Ethiopia \\ (e-mail: habte023@yahoo.com) \\ ${ }^{3}$ National and Local Joint Engineering Research Center for Rural Land Resources Use and \\ Consolidation, 210095 Nanjing, China \\ *Corresponding author \\ e-mail:ww@njau.edu.cn
}

(Received $25^{\text {th }}$ Jul 2018; accepted $31^{\text {st }}$ Oct 2018)

\begin{abstract}
Ecological values of land use are important for the survival of human beings. Understanding their dynamic nature is essential for appropriate decisions. However, most often, economic value quantification has received major emphasis whereas ecological values are mostly overlooked, especially in developing countries. With the aim of quantifying ecological values of land use via criteria-based farmer's assessments and empirically analyzed soil properties, three land use types [conservation tillagebased agroforestry land (CTAFL), conventional tillage-based cultivated land (CVTCL) and enclosurebased communal land (ECL)] were selected. Criteria-based scoring was used and 90 farmers participated. For soil analysis, sample collection was done following sampling procedures. The results show that farmers have higher preference for CTAFL followed by ECL and CVTCL. This was due to higher ecological values derived from the CTAFL throughout the year with minimum variation compared to CVTCL and ECL. Almost all measured soil variables exhibited significant variation $(p<0.001)$ among land use type. Almost all soil variables exhibited higher mean values for CTAFL and this supported the results of the farmers' assessments. All ecological value improvements observed for CTAFL were related to clay fractions coupled with the SOC content and degree of soil disturbance. This result implies that conservation and participation based land management is a means to obtain sustainable ecological benefits from land use types.
\end{abstract}

Keywords: ecological value, communal land, conservation tillage, criteria-based scoring, soil properties

\section{Introduction}

Quantification of ecological values of land use types is an essential part of land use planning (Feng et al., 2014) that is often used for appropriate land use decision-making and implementation processes (Braimoh and Vlek, 2008; Itanna et al., 2011; Feng et al., 2014). It can be observed as the link between the science of ecology and the actual practice of land use type management (Geneletti, 2006). In the past few decades, there has been a growing of interest in the science of land use type functions and its ecosystem services provided since the release of the millennium ecosystem assessment. Land use types provide different ecological values or functions to human beings (Duguma and Hager, 2011; Feng et al., 2014). However, the values or functions derived from these land use types by human beings should be quantified to avoid further land 
degradation. Evaluation of ecological values of land use types helps decision makers to balance the actual existing land use type resources and human demands (Liu et al., 2014). Currently, different countries have faced challenges in balancing land use type resources and the alarmingly increasing human population and its demands (De Groot et al., 2012). On the other hand, due to the continuous interactions of inhabited component's of land use types and the processes occurring within these areas, the ecological values of land use types has high spatial and temporal heterogeneity (De Groot et al., 2002; Wade et al., 2008). As a result, it is found to be difficult to obtain absolute means for evaluating land use values (especially non-marketable goods and services) rather than understanding them in relative terms.

The benefits derived from land use types can be broadly categorized as economic, ecological and social (De Groot et al., 2002, 2012; Duguma and Hager, 2011). However, their benefits depend on characteristics of their biotic components and management activities. Most scholars focus on the economic aspects of evaluating ecosystem services of land use types, and hence, there have been scant evaluation of land use types in terms of ecological values. Scholars (such as MEA, 2005) have noted that the ecological benefits of land use types are widely recognized but poorly understood and further indicated that most management decisions about land use types are made based on potentially marketable goods that can be easily extracted. As a result, non-marketable ecological values of land use types are often left unobserved by most scientific communities. Quantification of the ecological values of land use types using multiple criteria can have tremendous impact on the land use decision-making processes employed by farmers. The approach has a capacity to induce active participation of the farmers. It has also an advantage in terms of validation of the results because most of the intangible ecological values of all land use types are considered by farmers. Therefore, it is imperative to use a criteria-based approach and allow farmers to participate in the processes of evaluating land use types.

Understanding ecological/ecosystem services of land use types from soil performance using indicator or dynamic approaches is also essential for land use decision-making. Greiner et al. (2017) tried to place the contribution of soil to ecosystem services in a cascading framework from soil properties and functions to the benefits derived from them through the impact on land use types. The soil as natural capital is able to support the delivery of ecosystem services which makes the soil as one of key components of terrestrial ecosystem. Despite its importance, most studies (De Groot et al., 2002; Duguma and Hager, 2011; Comerford et al., 2013; Adhikari and Hartemink, 2016; Costantini, 2016; Leemans and de Groot, 2003) explain ecosystem services with minimal focus on the performance of soils. Moreover, studies performed by (Dominati et al., 2010; Breure et al., 2012; Pereira et al., 2018) argue that soil components have been overlooked as vital resources, despite the fact that soils are key for enhancing ES and ecological values of the land use type. Soil as a system needs emphasis (Pereira et al., 2018) because it influences the ecological values of land use types directly or indirectly through its properties and the processes undertaken within it (Costanza et al., 2010; Greiner et al., 2017). Therefore, examining soil properties as indicators of land use performance is helpful for obtaining a further detailed understanding of soil ecosystem services and their reciprocal effects.

Soil performance can be undermined by different agents, including both natural and anthropogenic sources. Among these, soil degradation is highly noted (Adhikari and Hartemink, 2016; Negasa et al., 2017; Pereira et al., 2018). It is a widespread problem 
in East Africa, particularly in Ethiopia. It causes deterioration of ecological/ecosystem service values of the soil. It negatively affects the provisioning, supporting and regulating service of the soil (Pereira et al., 2018). Such problems are commonly observable on land use types managed by unsustainable practices. For instance, intensive and frequent cultivation of soil decreases soil biomass, organisms, and carbon content and increases soil compaction, erosion, acidification and salinization (Costantini, 2016; Greiner et al., 2017). Therefore, sustainable soil and land use type management practices have important implications for the quantity and quality of ecological/ecosystem services provided by soil and the land use itself.

Three land use types predominant in the study landscape. These are: conservation tillage based agroforestry land (CTAFL), conventional tillage based cultivated land (CVTCL) and enclosure based communal land (ECL). These land use types have been managed differently using farmers' indigenous knowledge (Kanshie, 2002; Kura, 2013). Traditional farming equipments such as hand hoes and Maresha (Ketema and Yimer, 2014; Negasa et al., 2017) have been commonly used by farmers. To minimize land degradation and improve the ecological values of the land use types, different measures have been implemented in the area including agroforestry systems and soil conservation measures. Despite the fact that some conservation practices are implemented to improve the ecological values of land use types (Temesgen et al., 2018a), to the best of our knowledge, the ecological values of the land use types are not well studied. Except Temesgen and $\mathrm{Wu}$ (2018), the few studies conducted in the area were mainly focused on species diversity, biomass, carbon sequestration and indigenous knowledge transfer practices (Kanshie, 2002; Kura, 2013; Negash and Kanninen, 2015) in addition to soil properties according to the age of land use type (Ketema and Yimer, 2014) and toposequence (Negasa et al., 2017). Few studies focused on quantifying the ecological values of land use types via criteria-based farmers' assessment and empirically analyzed soil properties have been found. In this work, we aimed to compare the ecological values/ecosystem services of the three land use types from the perspective of farmers' assessments and soil properties. This study therefore focused on the following basic research questions:

1. Does the enclosure-based communal land use type (ECL) possess greater ecological values compared to individually owned conservation tillage-based agroforestry land (CTAFL) and conventional tillage-based cultivated land (CVTCL)?

2. What empirical evidence has been obtained from the soil as a result of land management applied on each land use type that positively or negatively affects the ecological values of the land use system?

3. What relationship is there between farmers' ecological value assessments and the results of soil empirical analysis of land use types?

\section{Materials and methods}

\section{Description of the study area}

The research was conducted in Wonago district (Fig. 1) located on the southeastern escarpment of the Ethiopian rift valley (Negasa et al., 2017). Hydrologically, the area is located in the Gidabo watershed. The upper-lying area of the watershed is the source of many perennial rivers that usually feed Abaya-Chamo Lake. The altitude of the area 
ranges from 1400-1800 $\mathrm{m}$ asl. Geographically, it extends between $6^{\circ} 15^{\prime} \mathrm{N}$ to $6^{\circ} 26^{\prime} \mathrm{N}$ latitude and $38^{\circ} 10^{\prime} \mathrm{E}$ to $38^{\circ} 12^{\prime} \mathrm{E}$ longitude.

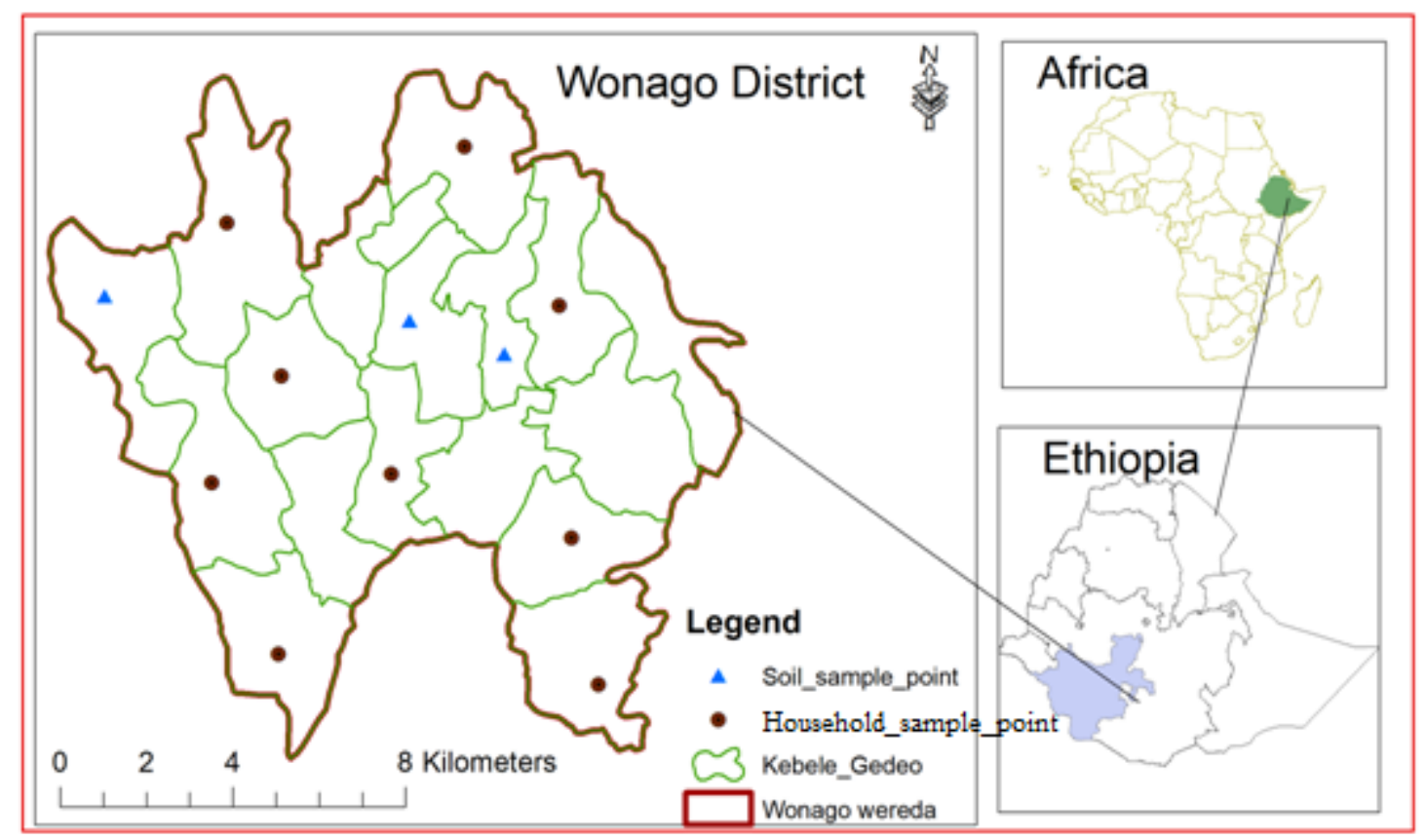

Figure 1. Map of the study area

The area is characterized by a bimodal rainfall distribution with a maximum between March and July and minimum between August and October (Fig. 2). The mean annual rainfall and temperature of the study area range from 1200 to $1800 \mathrm{~mm}$ and from 15.10 to $22.5^{\circ} \mathrm{C}$, respectively.

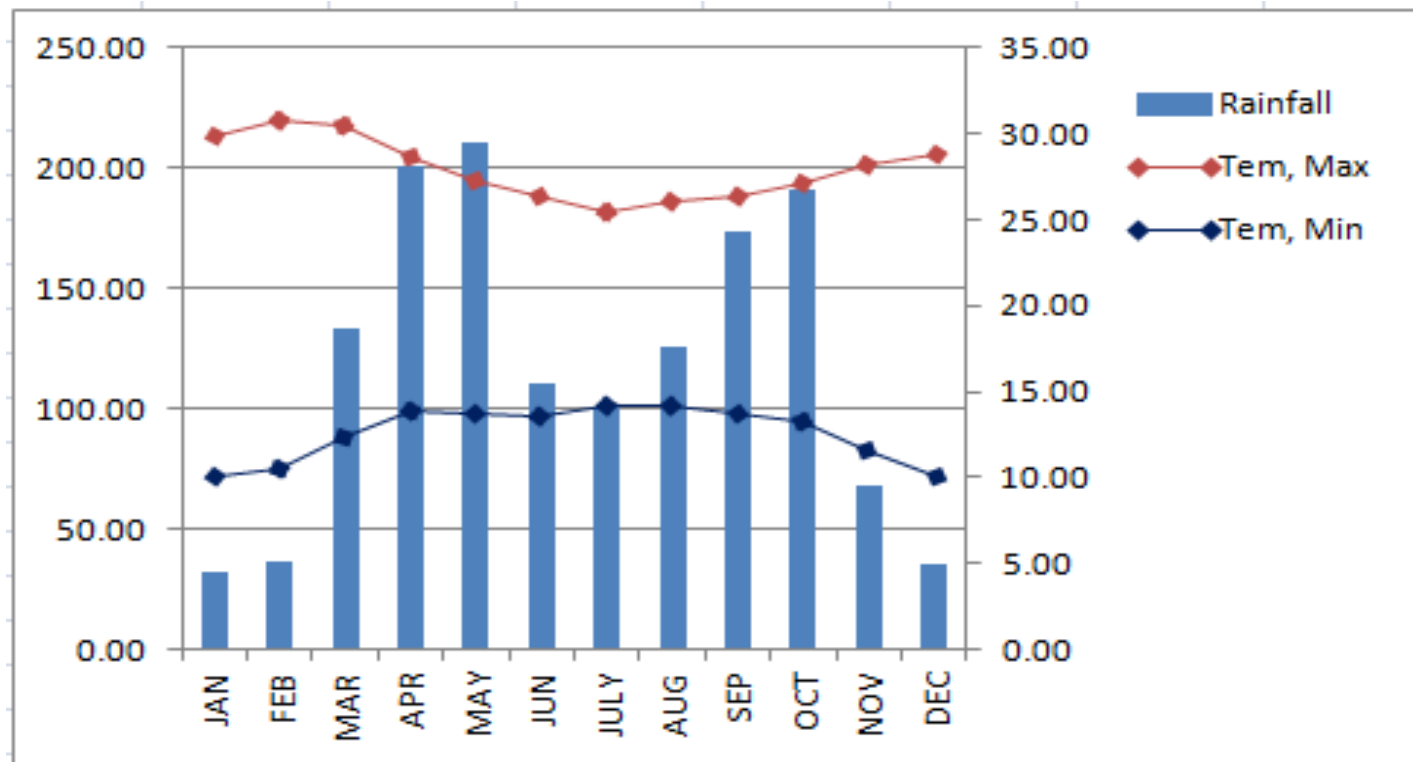

Figure 2. Mean monthly rainfall $(\mathrm{mm})$ and temperature $\left({ }^{\circ} \mathrm{C}\right)$. (Source: National Meteorological Services Agency (NMSA) of Ethiopia, 2017) 
The land use system of the area is not purely crop farming (CVTCL); rather there are also agroforestry systems (CTAFL) and enclosure area (ECL) (hereafter known as land use types). The first two are owned by individual small holder farmers whereas the third land use type is owned by the whole community. The local farmers produce cereals using traditional farm equipment known as "Maresha" (Fig. 3). The plowing system is simple with shallow tilling to a soil depth of $15 \mathrm{~cm}$ on average. This traditional tillage implement is commonly drafted by oxen (Gebregziabher et al., 2006). Because of its Vshaped plowing via Maresha, the local farmers have to perform repeated tillage (24 times per season) with any two consecutive tillage operations performed perpendicular to each other. As a result, the soil is pulverized resulting in weak soil structure and compact formation (Ketema and Yimer, 2014). Moreover, the local farmers usually remove crop residues from cultivated land after harvest for either wood or animal feed. Thus, no crop residue remains in the field each season for either mulching or organic matter amendment to the soil (Ketema and Yimer, 2014; Negasa et al., 2017).

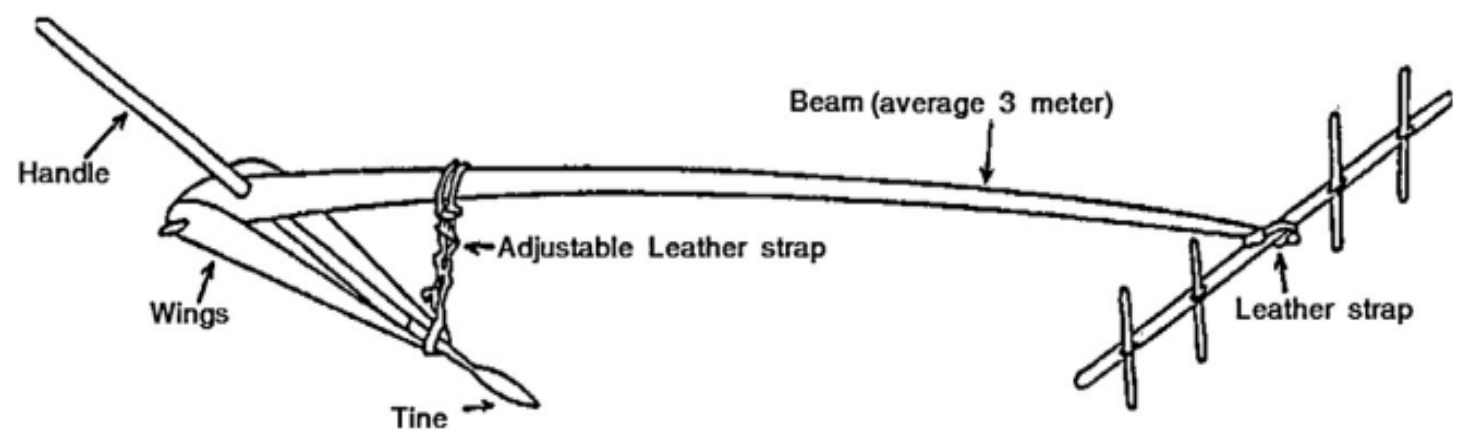

Figure 3. Traditional plowing equipment by oxen

The agroforestry land use type (CTAFL) of the area is well known due to it being a traditional means of life for the local people. Hand hoe is traditional farming equipment used for the agroforestry system (Fig. 4). Perennial trees (Millettia ferruginea, Ficus vasta and Erythrina abyssinica) and annual crops intermingle mostly in mutual coexistence. The local farmers leave weedy herbaceous materials on top of the soil with the objectives of mulching and addition of organic matter to the soil system. Therefore, nutrient cycling and soil protection from erosive forces and inducing rainwater to percolate into the soil are advantages derived from the system.

The communal land, which was recently changed to the enclosure land use type, was initially used as grazing land by the local people. However, after years of continuous usage, it was totally changed into degraded and gully-dominated land. To curb the problem, the area was changed to enclosure area together with implementing biological and physical soil conservation measures intended to accelerate the land restoration processes.

The dominant soil of the study region is chromic luvisol (Kanshie, 2002). Chromic Luvisol has good agricultural potential. It is characterized by Argillic B horizon due to accumulation of clay in the subsurface (Ketema and Yimer, 2014; Negasa et al., 2017). Clay is the dominant textural fraction in the study area. 


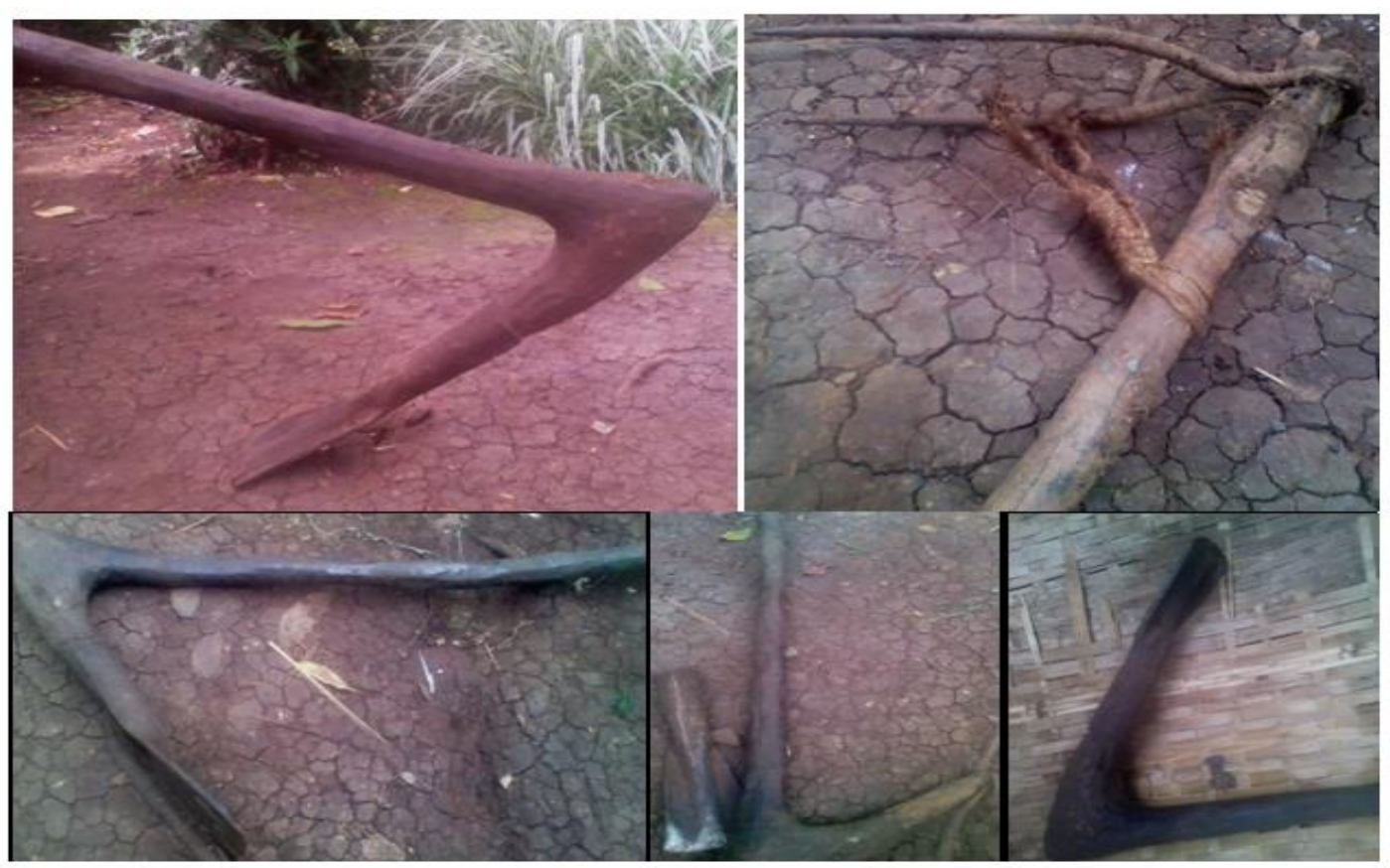

Figure 4. Traditional hand hoe tool used in agroforestry system. (Source: authors' field photo, 2018)

\section{Data collection and analysis}

Quantification of ecological values of the three major land use types under study was performed using four stages (Fig. 5). These were the following: (1) after identification of individual farmers using snowball techniques, on-site in-depth interviews were performed to understand farmers' perceptions about the ecological values of the land use types. The interview was conducted in February 2018 and lasted 1:00-1:30 h per interviewee and were focused on the bonds that exist between the farmers' households and land use types. The farmers' household characteristics were also given due emphasis during the interviews. (2) A criteria-based scoring approach was applied using a famous local game known as the bao game. (3) Focus group discussion (FGD) was held with selected respondents (10 key informants identified) to consolidate and explain the reason behind the bao game rating values and the potential of the land use types in providing the selected ecological values to the local people. For better visual understanding and explanation of farmers, a photo panel of each land use type was used for participants in the focus group discussion and bao game. The local knowledge of farmers obtained over years is essential for examining the intangible ecological values of land use types. Therefore, participatory techniques play a significant role in assessing the intangible ecological values of land use types. (4) For empirical soil analysis, soil data were collected from three land use types (Table 1). The same land use types were used for soil data collection and farmers' assessments.

Bio game is a traditional game played in most East Africa countries (Duguma and Hager, 2011; Temesgen and $\mathrm{Wu}, 2018$ ). It is an approach used to draw out farmers' ratings of and reasoning about the ecological values of different land use types. In Ethiopia, the game is commonly played by rural people. It is played by group of people sitting around a board that is either a wooden board or smoothed ground with holes used 
for placing play balls (mainly seeds) inside. The numbers of holes on the board are different at different places, but for this research, we used board with an $8 * 2$ matrix to place the rankings of five ecological values (five criteria) for three land use types. The scoring procedure was applied to 90 respondents with a 0-5 Likert scale, with 0 and 5 representing the lowest and highest ecological values of the land use types, respectively. For scoring land use types, respondents used seeds of haricot bean (a common seed available in the area), where farmers counted the seeds and placed them in the bao game board hole. To minimize farmers' confusion, each land use type was considered one by one according to the five criteria. Different scholars (Franzel et al., 1995; Mafongoya and Kuntashula, 2005) have used this game for different participatory research activities, such as for selection of multi-purpose tree species and soil fertility evaluation in Western Kenya and socio-cultural and ecological ecosystem service valuation in the southeastern escarpment of the Ethiopian rift valley (Temesgen and $\mathrm{Wu}, 2018$ ) and central highland.

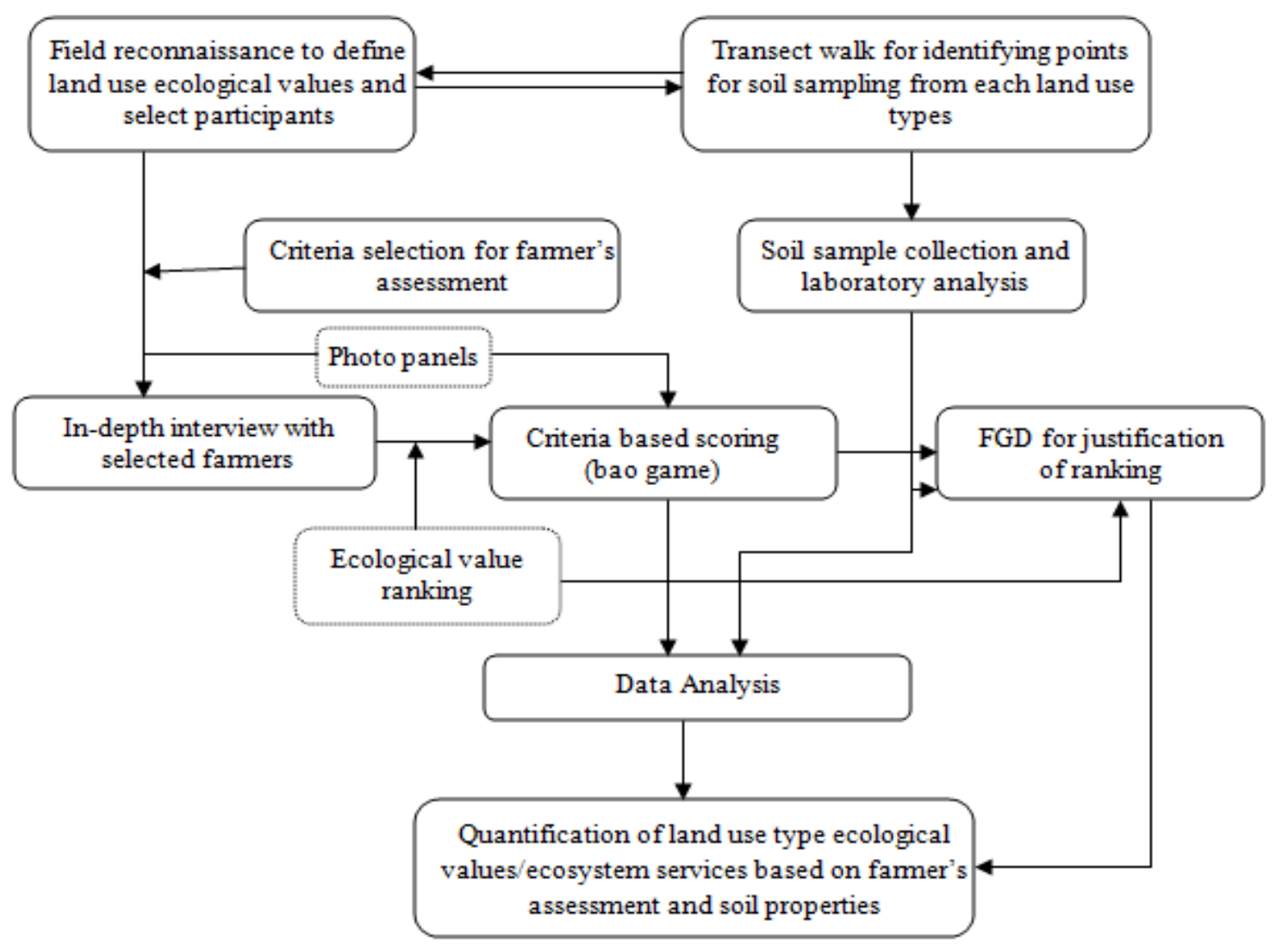

Figure 5. Conceptual framework of the study

The selected land use types are contiguous to each other and have similar environmental conditions. Each land use type was categorized into three slope positions (upper, middle and lower slope), and soil data were collected from each slope position following the transect line. Factorial analysis with an RCBD design was employed. A total of 54 composite soil samples ( 3 slope positions $* 3$ land use types $* 3$ replications * 2 soil depths, with soil depths of 0-20 and 20-40 cm) were collected in February 2018. The soil samples were air-dried, crashed, and passed through a 2-mm-diameter sieve. 
Undisturbed soil samples were also collected for the purpose of determining of the soil bulk density (Hillel, 2004). The soil textural fractions (USDA, 1972), soil organic carbon (Schnitzer, 1982), bulk density, cation exchange capacity, total nitrogen (Bremner and Mulvaney, 1982), soil pH, soil electrical conductivity, soil moisture content (Cuenca, 1989) and soil total porosity (Oguike and Mbagwu, 2009) were determined following standard procedures. The number of macro-organisms observed by the naked eye in the soil sample was determined using simple counting techniques (Negasa et al., 2017). For evaluating the hydraulic conductivity of the land use types, a double-ring infiltrometer was used (Bertrand, 1965). The design used during the measurement was 3 land use types $* 9$ time rates $* 2$ replications. Therefore, a total of 54 infiltration measurements were obtained.

Table 1. Selected land use types and their descriptions

\begin{tabular}{c|l}
\hline Land use type & \multicolumn{1}{|c}{ Description } \\
\hline $\begin{array}{c}\text { Conservation tillage-based agroforestry } \\
\text { land (CTAFL) }\end{array}$ & $\begin{array}{l}\text { It is a traditionally managed agroforestry system where annual } \\
\text { and perennial crops grow together with the concepts of } \\
\text { conservation tillage practices. It is owned by individual farm } \\
\text { households and has no physical soil conservation measures }\end{array}$ \\
\hline $\begin{array}{c}\text { Conventional tillage-based cultivated } \\
\text { land (CVTCL) }\end{array}$ & $\begin{array}{l}\text { Cropping field cultivated with conventional practice using } \\
\text { traditional equipment (Maresha) 2-4 times per season. It is } \\
\text { owned by individuals and has soil bund and faniyaa juu } \\
\text { conservation structures for the sake of minimizing soil erosion } \\
\text { in the area }\end{array}$ \\
\hline Enclosure-based communal land (ECL) & $\begin{array}{l}\text { This is a land owned by the community and controlled by } \\
\text { Kebele leaders and community nominated groups. It is a closed } \\
\text { area with no human and animal interference. Each year the } \\
\text { community constructs and maintains different soil and water } \\
\text { conservation structures on the land use in campaign. Cut and } \\
\text { carry system is only allowed for local farmers }\end{array}$ \\
\hline
\end{tabular}

\section{Criteria selection for evaluating ecological values of land use types}

A snowball technique was used to select respondents who were able to list ecological values associated with any land use types in their localities. Snowball sampling is a technique used to select respondents who are knowledgeable about the ecological values of the land use types in the area. The name reflects an analogy with a snowball increasing in size as it rolls downhill. Every respondent involved can suggest another respondent who they think would be able to offer more information about the ecological values of the land use types in question. In doing so, 100 respondents in total were selected, out of which 90 were for scoring and 10 were for listing the scoring criteria. During this participatory listing of criteria, maximum precaution was taken to avoid repetition of criteria with similar ideas. After listing 10 criteria, respondents were asked to list the main five criteria (Table 2) that they believed could able to represent the ecological values of the land use types in question.

\section{Data analysis}

Descriptive statistics and analysis of variance (ANOVA) were used to analyze the data. The scores given to the five criteria were obtained as quantities measured on a continuous scale. Computation of ecological values of each land use types was 
performed by summing the scores given by each respondent. The relative importance was also computed by dividing the mean values scores by the sum of mean of the five criteria and multiplying by 100 to obtain percentage values. Laboratory results were analyzed using the General Linear Model (GLM) procedure implemented in the SPSS version 20.0 for Windows software package. Tukey's Honest Significance Difference (HSD) test was used when the mean separation exhibited statistically significant differences $(\mathrm{p}<0.05)$.

Table 2. Definition of ecological values as per the local context given by the farmers

\begin{tabular}{c|l}
\hline Criteria & \multicolumn{1}{c}{ Description } \\
\hline $\begin{array}{c}\text { Ecological values } \\
\text { (MSE) }\end{array}$ & $\begin{array}{l}\text { The potential of the land use to reduce soil erosion, presence of deep and } \\
\text { fertile top soil, organic matter and ability to grow tree seedlings and grasses }\end{array}$ \\
\hline $\begin{array}{c}\text { Improve water availability } \\
\text { and infiltration (IWAI) }\end{array}$ & $\begin{array}{l}\text { The ability of the land use to hold soil moisture within it and able to give as } \\
\text { water sources such as springs for utilization, minimum or no observation of } \\
\text { flooding or run-off }\end{array}$ \\
\hline $\begin{array}{c}\text { Feed source for animals } \\
\text { (FSA) }\end{array}$ & $\begin{array}{l}\text { The values of the land use to provide feeds for animals through cut and } \\
\text { carry system or direct feeding throughout the year or during dry season }\end{array}$ \\
\hline $\begin{array}{c}\text { Micro-climate improvement } \\
\text { (MCI) }\end{array}$ & $\begin{array}{l}\text { The ability of the land use to create conducive climatic conditions in the } \\
\text { area (Farmers expressed as: when we get outside, we able to get free and } \\
\text { clean oxygen) }\end{array}$ \\
\hline $\begin{array}{c}\text { Soil fertility improvement } \\
\text { (SFI) }\end{array}$ & $\begin{array}{l}\text { The capacity of the land use to improve its soil fertility from its organic } \\
\text { matters, minimize the washing effects of run-off or rainfall and in the area }\end{array}$ \\
\hline
\end{tabular}

\section{Results and discussion}

\section{Criteria-based evaluation of ecological values of land use types}

\section{Relative importance (RI) of land use types}

The relative importance shows how important each of the given criteria is relative to other criteria for a given values of land use type. All the criteria listed by farmers (Table 3) had nearly equal importance to the area and received complementary or competitive contributions from each land use types in the study region. It was clearly noted from the farmers' FGD results that conservation tillage-based agroforestry land (CTAFL) use has a complementary effect on each ecological value criterion and land use type. Table 3 indicates that more than $60 \%$ of the mean scores for the ecological values of CTAFL received mean values of $>4.5$ (MSE, IWAI \& SFI), whereas the remaining $40 \%$ had mean values of $>3.5$ (FSA \& MCI). The higher ecological values gained from CTAFL (for instance, increased animal feed sources and higher soil fertility) could be a relief and opportunity to consolidate other land use types. Almost $67 \%$ of the mean score for ecological values of the conventional tillage-based cultivated land (CVTCL) use type received mean values of less than or equal to 2.5. Due to continuous soil disturbance, all ecological values perceived by farmers were low, and this land use type has competitive effects on itself (CVTCL) and on other land use types.

Similarly, more than $60 \%$ of the mean score for enclosure based communal land (ECL) use had RI greater than 20\% (Table 3). Therefore, based on the sum of the mean 
score and overall farmers' preferences, the ecological values of land use type were ranked as CTAFL > ECL > CVTCL in the study region.

The highest preference for the CTAFL land use type was due to its complementary effect either in increasing production or in reducing soil erosion which has been a common scenario of the country as a whole (Bewket and Sterk, 2003; Temesgen et al., $2018 \mathrm{~b}$ ). Regarding the knowledge of farmers, the higher preference for CTAFL was due to four major issues: (1) the presence of different annual/perennial plants and herbaceous weeds on it, (2) the presence of plant density, (3) the diversity of agroforestry components in forming vertical strata (important for rainfall interception and shed for understory crop/plant species, and (4) the advocacy of government officials and development agents concerning multiple functions of the CTAFL land use type for improving the watershed. Furthermore, the role in maintaining soil fertility and keeping the soil moisture always "wet" are the main reasons for higher preference of farmers for the CTAFL land use type. This study agrees with research findings of Temesgen and $\mathrm{Wu}$ (2018), which states that the agroforestry land use type is the dominant ecological/ecosystem service provider and is most preferred by farmers, while cultivated land receives the least preference in the southeastern rift valley escarpment of Ethiopia. Duguma and Hager (2011) also observed a higher preference of farmers for land use types with homestead trees and shrubs and the weakest preference red cultivated land in the central highlands of Ethiopia.

\section{Minimizing soil erosion (MSE) and improving water availability and infiltration (IWAI)}

Land use types either positively or negatively affects soil erosion, soil water availability and infiltration (Ketema and Yimer, 2014; Negasa et al., 2017). The CTAFL and ECL land use types have higher contribution in minimizing soil erosion $(91.2 \%$ and $0.6 \%$, respectively) and improving water availability and infiltration (93.88\% and $5.56 \%$, respectively) relative to the CVTCL land use type. These highly valued ecological services in the study region indicate that there is a consensus between farmers' perception and the existing scientific literature. The CTAFL land use type's role in MSE and IWAI is in agreement with the general principles of agroforestry systems. The anchoring effects of diversified plant species by their roots and rainfall interception role of their branches, litter fall and dead plants available on the surface have played significant roles in MSE and IWAI on both CTAFL and ECL land use types. This assertion is supported by Kanshie (2002), Kura (2013) and Temesgen and Wu (2018). Similar conclusions were also reached by other studies, such as Lal (2003). Due to CTAFL, the local farmers have accessed water points nearby their village, and this encouraged them to spatially expand agroforestry system, even towards the lowland part of the study region.

Despite it being owned by the community and lacking some procedures for using its resource by the community (who are entitled to rights of use), the ECL land use type has positively impacted soil erosion and water availability in the area. Every year, all the local farmers contribute free labor voluntarily for maintenance in addition to construction of new SWC measures (Mazengia et al., 2007; Habtamu, 2011). The free labor contributions of farmers have improved the ecological values of land use types and at the least they have reduced or avoided competition with other agricultural practices (Tefera et al., 2005; Mazengia et al., 2007). However, CVTCL was least favored in MSE and IWAI compared to CTAFL and ECL land use types (Table 3). During FGD with key informants, three important points were raised as the main 
reasons for these preferences: (1) poor attention to crop land management (e.g., lack of maintenance of SWC structures, low input such as manure and compost, and no crop residue left after harvest), (2) frequent tillage (at least 2-4 times per season) and (3) inappropriate land use practices (a failure to link the right land use practice to the right land use type). Moreover, since the land use type is open land with no cover, crust formation after rainfall may enhance soil erosion in the area. This result is in agreement with findings of Wade et al. (2008) and Duguma and Hager (2011), in which the minimum ecological values were observed for cultivated land due to the problem of soil erosion.

Table 3. Relative importance of land use types determined using the criteria-based scoring approach

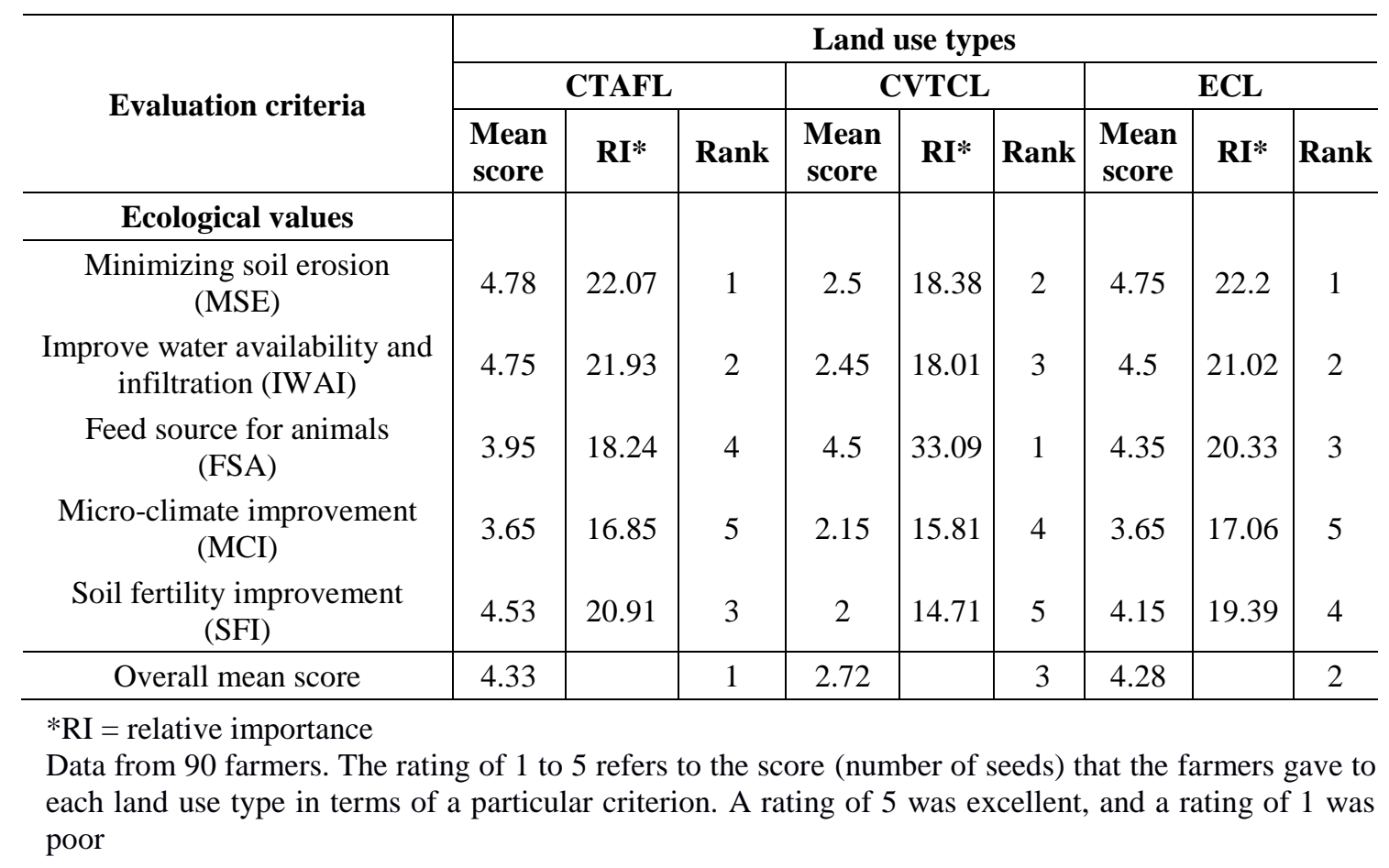

\section{Source of feed for animals (FSA) and soil fertility improvement (SFI)}

CVTCL was the most preferred land use type due to it being a source of feed for animals. Once it is harvested, the feed is used throughout the year, with some supplementary source from CTAFL and ECL land use types. Statistically (descriptive), CVTCL received a higher mean value (4.5) than ECL (4.35) and CTAFL (3.95). During the focus group discussion, farmers explained that the farming objective of the CVTCL land use type is not only to have a higher crop yield but also to have a higher biomass of crops for animal feed after harvest. With expansion of the CVTCL land use types and the resultant decrease in grazing resources, crop residues are becoming the main source of livestock feed in the study area (Tefera et al., 2005). Moreover, since free grazing of animals is not allowed, the farmers mostly use a cut-carry system to feed their animals in their gardens. Since CTAFL has diversified plants and herbs, it has an important role in providing animal feed for farmers. Farmers argued that the amount of feed derived from CTAFL is small but sustainable compared to feed sources obtained from CVTCL 
and ECL land use types. On the other hand, since ECL is communal land, farmers derive benefits in groups through cut-carry system. This is a good practice, although farmers have questioned the appropriateness of the harvest time and the benefits obtained from the land use (Alemayehu et al., 2013; Tefera et al., 2005).

The higher demand for animal feed from the CVTCL land use type has implications for the fertility of the soil. Failure to return or leaving crop residues on the soil has longterm effect on the soil productivity (Ketema and Yimer, 2014; Duncan et al., 2016; Negasa et al., 2017). In addition, frequent tillage practices on CVTCL and the subsequent soil compaction have exposed the land use for water and tillage erosion (Leye, 2007). CTAFL was strongly preferred by the farmers for improving soil fertility. The presence of litter fall, herbaceous weeds and various added household wastes are the main sources of soil fertility (Kanshie, 2002; Duguma and Hager, 2011; Araujo et al., 2012; Ketema and Yimer, 2014; Bagyaraj et al., 2015; Zake et al., 2015; Negasa et al., 2017). The ECL land use type has also played a dominant role in maintaining and improving the in situ soil fertility. However, farmers have identified associated sustainability problems, as they all want to maximize their benefits derived from this communal land use type in the study region.

\section{Empirically based evaluation of ecological values of land use types}

\section{Soil physical properties as indicator: textural fractions (\%) and bulk density $\left(\mathrm{g} \mathrm{cm}^{-3}\right)$}

The descriptive statistic indicated that, sand and clay soil textural fractions exhibited significant variation among the land use types $(p<0.001, p=0.002)$, respectively. Following the toposequence, sand, silt and clay varied significantly $(p=0.027$, $p=0.001$ and $p<0.001$, respectively) in all land use types. A higher sand fraction was available in ECL than in the CTAFL and CVTCL land use types (Table 4). Clay was the dominant (>50\% on average) textural fraction in the area, and it was higher for the CTAFL land use type. The higher clay on CTAFL (61.61\% average) land use type was most likely due to less soil erosion by rainfall (Ketema and Yimer, 2014; Negasa et al., 2017) and the contribution of parent material. Higher clay content was also observed for the CVTCL land use type. This was most likely due to formation of crumble soil from frequent tillage (2-4 times per season) (Andruschkewitsch et al., 2013; Wang et al., 2018).

The higher clay content especially for CTAFL has been recognized as one of the major causes of higher soil moisture availability in the soil (Wang et al., 2018). Adoption of conservation tillage (CTAFL) has been reported to improve soil properties such as the water holding capacity, texture, structure and organic matter content of the soil (Andruschkewitsch et al., 2013). CTAFL had higher moisture content than the other land use types (Table 6). This was due to (1) the intrinsic nature of the clay soil and (2) the presence of litter-fall and herbaceous weeds, which act as mulch in reducing water evaporation from the soil (Deru et al., 2017; Pardon et al., 2017).

The soil bulk density $\left(\mathrm{g} \mathrm{cm}^{-3}\right)$ was significantly influenced by land use type and soil depth ( $\mathrm{p}<0.001$, Appendix 1). A lower bulk density was observed for CTAFL relative to the CVTCL and ECL land use types following the land slope (Table 5). The overall average soil bulk densities for the three land use types, from the lowest to highest, were CTAFL $\left(0.99 \mathrm{~g} \mathrm{~cm}^{-3}\right)<$ ECL $\left(1.09 \mathrm{~g} \mathrm{~cm}^{-3}\right)<$ CVTCL $\left(1.15 \mathrm{~g} \mathrm{~cm}^{-3}\right)$. The upper layer $(0-$ $20 \mathrm{~cm}$ ) of the soil had lower bulk density in all land use types. The soil bulk density is highly related to the organic carbon content of the soil (Andruschkewitsch et al., 2013; 
Negasa et al., 2017; Wang et al., 2018). The lower bulk density for CTAFL and ECL was due to high SOC (\%) and higher root densities (Liu et al., 2018), which makes the soil more dominated by aggregates (Cardinael et al., 2017) and more resistant to soil erosion. Soil organism movement, plant root penetration and free air and water circulation and water infiltration (see Tables 7 and 8 ) in the soil are highly favored with lower soil bulk density (Pardon et al., 2017; Pereira et al., 2018; Liu et al., 2018; de Sosa et al., 2018). Low SOC (\%) due to frequent tillage and compaction due to human and animal trampling was the main cause of the high bulk density of the CVTCL land use type.

Table 4. Soil textural fractions (\%) in relation to land use types, soil depth (cm) and slope category

\begin{tabular}{|c|c|c|c|c|c|c|}
\hline \multirow{2}{*}{ Variables } & \multirow{2}{*}{ Land use } & \multirow{2}{*}{$\begin{array}{l}\text { Soil depth } \\
\text { (cm) }\end{array}$} & \multicolumn{4}{|c|}{ Slope category } \\
\hline & & & Upper & Middle & Lower & Overall \\
\hline \multirow{9}{*}{ Sand } & \multirow{3}{*}{ CTAFL } & $0-20$ & $17.67 \pm 2.4$ & $12.33 \pm 2.67$ & $15.67 \pm 0.67$ & $15.22 \pm 1.31^{\mathrm{a}}$ \\
\hline & & $20-40$ & $15.67 \pm 2.91$ & $9.00 \pm 1.15$ & $14.33 \pm 2.4$ & $13.00 \pm 1.53^{\mathrm{a}}$ \\
\hline & & Overall & $17.17 \pm 1.09^{\mathrm{a}}$ & $10.67 \pm 1.43^{\mathrm{b}}$ & $15.0 \pm 0.76^{\mathrm{ab}}$ & \\
\hline & \multirow{3}{*}{ CVTCL } & $0-20$ & $15.67 \pm 1.33$ & $21.00 \pm 9.02$ & $17.00 \pm 0.03$ & $17.89 \pm 2.75^{\mathrm{a}}$ \\
\hline & & $20-40$ & $27.00 \pm 5.29$ & $15.00 \pm 4.00$ & $22.33 \pm 7.33$ & $21.44 \pm 3.35^{\mathrm{a}}$ \\
\hline & & Overall & $21.34 \pm 0.72^{\mathrm{a}}$ & $18.00 \pm 2.62^{\mathrm{b}}$ & $19.67 \pm 0.49^{\mathrm{ab}}$ & \\
\hline & \multirow{3}{*}{ ECL } & $0-20$ & $21.00 \pm 2.00$ & $21.00 \pm 2.00$ & $23.67 \pm 5.21$ & $21.89 \pm 1.77^{\mathrm{a}}$ \\
\hline & & $20-40$ & $27.00 \pm 5.29$ & $15.00 \pm 4.00$ & $22.33 \pm 8.51$ & $21.44 \pm 3.35^{\mathrm{a}}$ \\
\hline & & Overall & $24.00 \pm 3.15^{\mathrm{b}}$ & $18.00 \pm 1.27^{\mathrm{c}}$ & $23.00 \pm 3.16^{\mathrm{bc}}$ & \\
\hline \multirow{9}{*}{ Silt } & \multirow{3}{*}{ CTAFL } & $0-20$ & $30.33 \pm 1.76$ & $22.00 \pm 0.03$ & $21.33 \pm 0.67$ & $24.56 \pm 1.55^{\mathrm{a}}$ \\
\hline & & $20-40$ & $28.00 \pm 3.6$ & $22.67 \pm 1.33$ & $21.33 \pm 2.4$ & $24.00 \pm 1.66^{\mathrm{a}}$ \\
\hline & & Overall & $29.17 \pm 1.78^{\mathrm{a}}$ & $22.34 \pm 0.72^{\mathrm{ab}}$ & $21.33 \pm 0.83^{\mathrm{b}}$ & \\
\hline & \multirow{3}{*}{ CVTCL } & $0-20$ & $33.67 \pm 4.67$ & $20.67 \pm 3.53$ & $18.00 \pm 1.15$ & $24.11 \pm 2.97^{\mathrm{a}}$ \\
\hline & & $20-40$ & $32.33 \pm 2.40$ & $22.00 \pm 0.03$ & $18.67 \pm 2.67$ & $24.33 \pm 2.30^{\mathrm{a}}$ \\
\hline & & Overall & $33.00 \pm 1.85^{\mathrm{a}}$ & $21.34 \pm 5.13^{\mathrm{ab}}$ & $18.34 \pm 0.78^{\mathrm{b}}$ & \\
\hline & \multirow{3}{*}{ ECL } & $0-20$ & $27.67 \pm 3.33$ & $31.33 \pm 1.33$ & $27.33 \pm 5.70$ & $28.78 \pm 2.05^{\mathrm{a}}$ \\
\hline & & $20-40$ & $27.67 \pm 2.40$ & $21.33 \pm 3.33$ & $24.67 \pm 3.71$ & $24.56 \pm 1.84^{\mathrm{a}}$ \\
\hline & & Overall & $27.67 \pm 2.15^{\mathrm{a}}$ & $26.33 \pm 1.45^{\mathrm{ab}}$ & $26.00 \pm 1.99^{\mathrm{b}}$ & \\
\hline \multirow{9}{*}{ Clay } & \multirow{3}{*}{ CTAFL } & $0-20$ & $52.00 \pm 3.06$ & $65.67 \pm 2.67$ & $63.00 \pm 1.15$ & $60.22 \pm 2.42^{\mathrm{a}}$ \\
\hline & & $20-40$ & $56.33 \pm 6.17$ & $68.33 \pm 1.76$ & $64.33 \pm 1.33$ & $63.00 \pm 2.59^{\mathrm{a}}$ \\
\hline & & Overall & $54.17 \pm 2.23^{\mathrm{a}}$ & $67.00 \pm 1.64^{\mathrm{b}}$ & $63.67 \pm 0.96^{\mathrm{b}}$ & \\
\hline & \multirow{3}{*}{ CVTCL } & $0-20$ & $50.67 \pm 5.46$ & $58.33 \pm 5.70$ & $65.00 \pm 1.15$ & $58.00 \pm 3.10 \mathrm{a}$ \\
\hline & & $20-40$ & $52.67 \pm 3.53$ & $67.00 \pm 1.15$ & $65.67 \pm 2.40$ & $61.78 \pm 2.62 \mathrm{a}$ \\
\hline & & Overall & $51.67 \pm 2.13^{\mathrm{a}}$ & $62.67 \pm 4.92^{\mathrm{b}}$ & $65.34 \pm 0.82^{\mathrm{b}}$ & \\
\hline & \multirow{3}{*}{ ECL } & $0-20$ & $51.33 \pm 4.67$ & $47.67 \pm 1.76$ & $49.00 \pm 10.26$ & $49.33 \pm 3.34^{\mathrm{a}}$ \\
\hline & & $20-40$ & $45.33 \pm 4.37$ & $63.67 \pm 6.36$ & $53.00 \pm 11.01$ & $54.00 \pm 4.71^{\mathrm{a}}$ \\
\hline & & Overall & $48.33 \pm 2.38^{b}$ & $55.67 \pm 2.43^{\mathrm{c}}$ & $51.00 \pm 4.94^{\mathrm{c}}$ & \\
\hline
\end{tabular}

Overall means followed by the same letter(s) across columns and rows are not significantly different $(\mathrm{p}=0.05)$ in terms of land slope, land use types and soil depth. CTAFL $=$ conservation tillage-based agroforestry land, $\mathrm{CVTCL}=$ conventional tillage based cultivated land and ECL $=$ enclosure based communal land. 
Table 5. Soil bulk density $\left(\mathrm{g} \mathrm{cm}^{-3}\right)$ as an indicator of the ecological values of land use types

\begin{tabular}{c|c|c|c|c|c|c}
\hline \multirow{2}{*}{ Variables } & \multirow{2}{*}{$\begin{array}{c}\text { Land use } \\
\text { types }\end{array}$} & \multirow{2}{*}{$\begin{array}{c}\text { Soil depth } \\
(\mathbf{c m})\end{array}$} & \multicolumn{3}{|c|}{ Slope category } & \multirow{2}{*}{ Overall } \\
\cline { 3 - 6 } & & Upper & Middle & Lower & \\
\hline & \multirow{3}{*}{ CTAFL } & $20-40$ & $0.98 \pm 0.09$ & $0.97 \pm 0.05$ & $0.87 \pm 0.03$ & $0.94 \pm 0.03^{\mathrm{a}}$ \\
& & Overall & $1.09 \pm 0.01$ & $0.95 \pm 0.03$ & $1.06 \pm 0.01$ & $1.03 \pm 0.02^{\mathrm{a}}$ \\
\cline { 3 - 6 } $\mathrm{BD}\left(\mathrm{g} \mathrm{cm}^{-3}\right)$ & \multirow{3}{*}{ CVTCL } & $0-20$ & $1.02 \pm 0.03$ & $1.22 \pm 0.04$ & $1.11 \pm 0.05$ & $1.12 \pm 0.04^{\mathrm{a}}$ \\
& & $20-40$ & $1.13 \pm 0.04$ & $1.28 \pm 0.04$ & $1.12 \pm 0.02$ & $1.18 \pm 0.03^{\mathrm{b}}$ \\
& & Overall & $1.08 \pm 0.03^{\mathrm{b}}$ & $1.25 \pm 0.03^{\mathrm{b}}$ & $1.12 \pm 0.03^{\mathrm{b}}$ & \\
\cline { 3 - 6 } & \multirow{3}{*}{ ECL } & $0-20$ & $1.08 \pm 0.06$ & $0.77 \pm 0.4$ & $1.12 \pm 0.11$ & $0.9 \pm 0.13^{\mathrm{a}}$ \\
& & $20-40$ & $1.23 \pm 0.06$ & $1.14 \pm 0.03$ & $1.16 \pm 0.08$ & $1.17 \pm 0.03^{\mathrm{b}}$ \\
& & Overall & $1.16 \pm 0.05^{\mathrm{ab}}$ & $0.96 \pm 0.2^{\mathrm{ab}}$ & $1.14 \pm 0.06^{\mathrm{ab}}$ & \\
\hline
\end{tabular}

Overall means followed by the same letter(s) across columns and rows are not significantly different $(\mathrm{p}=0.05)$ with respect to land slope, land use types and soil depth. CTAFL $=$ conservation tillage-based agroforestry land, CVTCL = conventional tillage-based cultivated land and ECL = enclosure-based communal land.

\section{Gravimetric soil moisture content (SMC \%) and total porosity $\left(P_{t}\right)$}

Total porosity $\left(\mathrm{P}_{\mathrm{t}}, \%\right)$ and soil moisture content (SMC, \%) had significant variations with land use type $(\mathrm{p}<0.001, \mathrm{p}=0.01$, Appendix 1$)$ and soil depth $(\mathrm{p}<0.001$, $\mathrm{p}=0.04)$, respectively. Both total porosity $\left(\mathrm{P}_{\mathrm{t}}\right)$ and soil moisture content (SMC) were higher for CTAFL compared to the CVTCL and ECL land use types (Table 6). The overall average values of $\mathrm{P}_{\mathrm{t}}(\%)$ and $\mathrm{SMC}(\%)$ for the three land use types, from the highest to the lowest, were CTAFL (62.66\%) > ECL (59.10\%) > CVTCL (56.75\%) and CTAFL $(17.86 \%)>$ ECL $(14.98 \%)>$ CVTCL $(11.11 \%)$, respectively. In terms of soil depth, higher Pt (\%) was observed in the 0-20 cm-deep soil layer, and it has an inverse relationship with bulk density. However, higher amounts of SMC (\%) were observed at a soil depth of $20-40 \mathrm{~cm} . \mathrm{P}_{\mathrm{t}}(\%)$ and SMC (\%) are highly influenced by the inherent properties of the soil, including the bulk density and SOC (\%).

Table 6. Soil moisture content (SMC, \%) and total porosity $\left(P_{t} \%\right)$ as indicator of the ecological values of land use types

\begin{tabular}{|c|c|c|c|c|c|c|}
\hline \multirow{2}{*}{ Variables } & \multirow{2}{*}{$\begin{array}{l}\text { Land use } \\
\text { type }\end{array}$} & \multirow{2}{*}{$\begin{array}{l}\text { Soil depth } \\
\quad \text { (cm) }\end{array}$} & \multicolumn{3}{|c|}{ Slope category } & \multirow{2}{*}{ Overall } \\
\hline & & & Upper & Middle & Lower & \\
\hline \multirow{9}{*}{$\operatorname{SMC}(\%)$} & \multirow{3}{*}{ CTAFL } & $0-20$ & $12.35 \pm 0.54$ & $15.49 \pm 1.63$ & $7.2 \pm 2.35$ & $15.01 \pm 1.07^{\mathrm{a}}$ \\
\hline & & $20-40$ & $16.44 \pm 1.77$ & $20.91 \pm 2.45$ & $24.8 \pm 1.44$ & $20.72 \pm 1.44^{\mathrm{b}}$ \\
\hline & & Overall & $14.39 \pm 1.15^{\mathrm{a}}$ & $18.2 \pm 1.71^{\mathrm{a}}$ & $20.99 \pm 1.92^{\mathrm{a}}$ & \\
\hline & \multirow{3}{*}{ CVTCL } & $0-20$ & $10.94 \pm 0.87$ & $9.59 \pm 0.56$ & $7.53 \pm 1.21$ & $9.35 \pm 0.64^{\mathrm{a}}$ \\
\hline & & $20-40$ & $14.79 \pm 0.61$ & $13.13 \pm 1.11$ & $10.68 \pm 1.05$ & $12.87 \pm 0.71^{\mathrm{b}}$ \\
\hline & & Overall & $12.87 \pm 0.88^{\mathrm{a}}$ & $11.35 \pm 0.68^{\mathrm{b}}$ & $9.11 \pm 0.95^{\mathrm{a}}$ & \\
\hline & \multirow{3}{*}{ ECL } & $0-20$ & $11.14 \pm 0.03$ & $12.05 \pm 1.12$ & $16.4 \pm 1.30$ & $13.20 \pm 1.3^{\mathrm{a}}$ \\
\hline & & $20-40$ & $14.03 \pm 1.14$ & $16.12 \pm 0.70$ & $20.11 \pm 2.3$ & $16.75 \pm 2.1^{\mathrm{b}}$ \\
\hline & & Overall & $12.59 \pm 0.95^{\mathrm{a}}$ & $14.09 \pm 1.1^{\mathrm{a}}$ & $18.26 \pm 2.1^{\mathrm{b}}$ & \\
\hline
\end{tabular}




\begin{tabular}{c|c|c|c|c|c|c}
\hline & & $0-20$ & $63.01 \pm 3.53$ & $63.18 \pm 1.76$ & $67.07 \pm 1.05$ & $64.42 \pm 1.3 \mathrm{a}$ \\
& \multirow{3}{*}{ CTAFL } & $20-40$ & $58.66 \pm 0.48$ & $64.03 \pm 0.95$ & $60.01 \pm 0.34$ & $60.89 \pm 0.87^{\mathrm{b}}$ \\
& & Overall & $60.84 \pm 1.8^{\mathrm{a}}$ & $63.60 \pm 0.92^{\mathrm{a}}$ & $63.54 \pm 1.66^{\mathrm{a}}$ & \\
\cline { 3 - 7 } $\mathrm{P}_{\mathrm{t}}(\%)$ & \multirow{3}{*}{ CVTCL } & $0-20$ & $61.34 \pm 1.39$ & $53.96 \pm 1.29$ & $57.97 \pm 0.89$ & $57.76 \pm 1.34^{\mathrm{a}}$ \\
& & $20-40$ & $57.40 \pm 1.39$ & $51.77 \pm 1.65$ & $57.97 \pm 2.07$ & $55.74 \pm 1.2^{\mathrm{b}}$ \\
& & Overall & $59.40 \pm 1.24^{\mathrm{b}}$ & $52.87 \pm 1.1^{\mathrm{b}}$ & $57.97 \pm 1.01^{\mathrm{b}}$ & \\
\cline { 3 - 8 } & \multirow{3}{*}{ ECL } & $0-20$ & $59.04 \pm 2.10$ & $70.91 \pm 1.54$ & $57.64 \pm 4.16$ & $62.53 \pm 4.9^{\mathrm{a}}$ \\
& & $20-40$ & $53.68 \pm 2.37$ & $56.93 \pm 1.07$ & $56.40 \pm 3.03$ & $55.67 \pm 1.26^{\mathrm{b}}$ \\
& & Overall & $56.36 \pm 1.86^{\mathrm{ab}}$ & $63.92 \pm 1.23^{\mathrm{ab}}$ & $57.01 \pm 2.32^{\mathrm{ab}}$ & \\
\hline
\end{tabular}

Overall means followed by the same letter(s) across columns and rows are not significantly different $(p=0.05)$ with respect to land slope, land use types and soil depth. CTAFL $=$ conservation tillage-based agroforestry land, $\mathrm{CVTCL}=$ conventional tillage-based cultivated land and $\mathrm{ECL}=$ enclosure-based communal land

Specifically, the higher $\mathrm{P}_{\mathrm{t}}(\%)$ and SMC (\%) in CTAFL mainly resulted from the higher SOC (\%) (Ketema and Yimer, 2014; Negasa et al., 2017) and clay textural fractions. Moreover, the formation of stable soil aggregates in CTAFL contributed to the high percentage of soil $\mathrm{P}_{\mathrm{t}}(\%)$ and SMC (\%) (Oicha et al., 2010) compared to CVTCL and ECL. However, the abovementioned points were not as strongly observed for CVTCL as for CTAFL and ECL. This result means that the ecological values or ecosystem services provided by the soil would be negatively affected by unsustainable soil management practices (Deru et al., 2017; Pereira et al., 2018).

\section{Water infiltration as an indicator of the ecological values of land use}

The water infiltration rate significantly varied with respect to land use type for the separate time increments $(\mathrm{p}<0.001)$. The overall mean value of the water infiltration rate was higher for the CTAFL (Table 7; Fig. 6) land use type than for ECL and CVTCL.

Table 7. Water infiltration rate of soil $(\mathrm{cm} / \mathrm{min})$ as indicator of the ecological values of land use types

\begin{tabular}{c|c|c|c|c}
\hline \multirow{2}{*}{ Variables } & $\begin{array}{c}\text { Measuring time } \\
\text { (min) }\end{array}$ & CTAFL & CVTCL & ECL \\
\cline { 2 - 4 } & 1 & $5.85 \pm 0.55$ & $1.35 \pm 0.38$ & $2.75 \pm 0.35$ \\
& 2 & $5.28 \pm 0.45$ & $1.33 \pm 0.32$ & $2.15 \pm 0.40$ \\
& 5 & $3.93 \pm 0.35$ & $1.06 \pm 0.34$ & $1.85 \pm 0.22$ \\
& 10 & $3.1 \pm 0.32$ & $0.98 \pm 0.37$ & $1.50 \pm 0.23$ \\
Infiltration rate & 15 & $2.74 \pm 0.13$ & $0.79 \pm 0.22$ & $1.25 \pm 0.31$ \\
$(\mathrm{~cm} / \mathrm{min})$ & 20 & $2.51 \pm 0.15$ & $0.54 \pm 0.02$ & $1.00 \pm 0.31$ \\
& 30 & $2.15 \pm 0.20$ & $0.45 \pm 0.01$ & $0.77 \pm 0.29$ \\
& 40 & $1.92 \pm 0.16$ & $0.40 \pm 0.01$ & $0.73 \pm 0.28$ \\
& 60 & $1.61 \pm 0.12$ & $0.34 \pm 0.01$ & $0.65 \pm 0.25$ \\
\hline
\end{tabular}

CTAFL $=$ conservation tillage-based agroforestry land, CVTCL $=$ conventional tillage-based cultivated land and ECL = enclosure-based communal land. 
The land use performance was ranked as follows: CTAFL > ECL > CVTCL. The infiltration rate of CTAFL was $129 \%$ and $293.9 \%$ higher than those of the ECL and CVTCL land use types. Similarly, the ECL land use type had a $71.95 \%$ higher water infiltration rate compared to CVTCL. The higher infiltration rate for CTAFL was due to the presence of higher porosity and crumbliness (Deru et al., 2017), high SOC (\%), soil aggregates and channels formed by live/dead plant root density (Deru et al., 2017). Similarly, the higher infiltration rate for ECL was connected with the land rehabilitation/restoration efforts made so far on the land use type. On the other hand, soil compaction, erosion and structural deteriorations due to frequent tillage practice were most likely the main reasons for the minimum infiltration rate on CVTCL land use type. This result agrees with the findings of Ketema and Yimer (2014) and Negasa et al. (2017), where a lower infiltration rate was obtained for conventionally tilled land use types.

Soil chemical properties as indicators: Soil $\mathrm{pH}\left(\mathrm{pH}-\mathrm{H}_{2} \mathrm{O}, 1: 2.5\right), \mathrm{EC}\left(\mathrm{EC}, \mathrm{ds} \mathrm{m}^{-1}\right)$ and CEC

Statistically, the soil $\mathrm{pH}$ value was significantly influenced by land use type and land slope $(\mathrm{p}<0.001$, Appendix 1). The overall average $\mathrm{pH}$ values for the three land use types, from the highest to lowest (Table 8), were CTAFL (6.2) > ECL (5.88) > CVTCL (5.81). The highest amount was obtained from CTAFL, whereas the lowest was from the CVTCL land use type. A higher amount of soil $\mathrm{pH}$ was also obtained on the middle slope relative to the upper and lower slopes of land use types. This might be attributed to some depositional accumulation of basic nutrients (positively charged cations) responsible for the increased $\mathrm{pH}$ values in the area. The $\mathrm{pH}$ value was found to be between 5.6 and 6.38 and was classified as weak acid. The lower the acidic content of the soil is, the more suitable it is for low-pH-loving macro-organisms and $\mathrm{pH}$-dependent soil nutrients (basic cations; see Table 10) (Pardon et al., 2017; Pereira et al., 2018; Negasa et al., 2017). Similarly, the soil electrical conductivity (EC, $\mathrm{ds}^{-1}$ ) and cation exchange capacity (CEC) were significantly influenced by land use type $(\mathrm{p}<0.001)$. Relatively higher EC (0.09) and CEC (42.05) were obtained for the CTAFL land use type. For both values, the overall means, from high to low, were in the order CTAFL > ECL > CVTCL.

Table 8. Soil $\mathrm{pH}\left(\mathrm{pH}-\mathrm{H}_{2} \mathrm{O}, 1: 2.5\right), E C\left(E C, d s \mathrm{~m}^{-1}\right)$ and $\mathrm{CEC}$ as indicators of the ecological values of land use types

\begin{tabular}{c|c|c|c|c|c|c}
\hline \multirow{2}{*}{ Variables } & \multirow{2}{*}{$\begin{array}{c}\text { Land use } \\
\text { types }\end{array}$} & \multirow{2}{*}{ Soil depth (cm) } & \multicolumn{3}{|c|}{ Slope category } & \multirow{2}{*}{ Overall } \\
\cline { 3 - 6 } & & $0-20$ & $6.13 \pm 0.09$ & $6.13 \pm 0.33$ & $6.53 \pm 0.15$ & $6.27 \pm 0.13^{\mathrm{a}}$ \\
& \multirow{3}{*}{ CTAFL } & $20-40$ & $5.73 \pm 0.12$ & $6.63 \pm 0.24$ & $6.07 \pm 0.26$ & $6.14 \pm 0.17^{\mathrm{a}}$ \\
& & Overall & $5.93 \pm 0.11^{\mathrm{a}}$ & $6.38 \pm 0.21^{\mathrm{b}}$ & $6.30 \pm 0.17^{\mathrm{c}}$ & \\
\cline { 3 - 6 } & & $0-20$ & $5.67 \pm 0.07$ & $6.33 \pm 0.26$ & $5.43 \pm 0.03$ & $5.81 \pm 0.16^{\mathrm{a}}$ \\
& \multirow{3}{*}{ CVTCL } & $20-40$ & $5.77 \pm 0.17$ & $5.90 \pm 0.12$ & $5.77 \pm 0.13$ & $5.81 \pm 0.07^{\mathrm{a}}$ \\
& & Overall & $5.72 \pm 0.08^{\mathrm{c}}$ & $6.12 \pm 0.16^{\mathrm{a}}$ & $5.60 \pm 0.1^{\mathrm{b}}$ & \\
\hline & & $0-20$ & $5.70 \pm 0.1$ & $6.20 \pm 0.12$ & $5.73 \pm 0.12$ & $5.87 \pm 0.09^{\mathrm{a}}$ \\
& \multirow{3}{*}{ ECL } & $20-40$ & $5.87 \pm 0.19$ & $6.03 \pm 0.27$ & $5.73 \pm 0.19$ & $5.87 \pm 0.12^{\mathrm{a}}$ \\
& & Overall & $5.78 \pm 0.1^{\mathrm{b}}$ & $6.12 \pm 0.14^{\mathrm{a}}$ & $5.73 \pm 0.1^{\mathrm{c}}$ & \\
\hline
\end{tabular}




\begin{tabular}{|c|c|c|c|c|c|c|}
\hline \multirow{3}{*}{$\mathrm{EC}$} & CTAFL & $\begin{array}{c}0-20 \\
20-40 \\
\text { Overall } \\
\end{array}$ & $\begin{array}{c}0.08 \pm 0.02 \\
0.06 \pm 0.02 \\
0.07 \pm 0.01^{\mathrm{a}}\end{array}$ & $\begin{array}{c}0.09 \pm 0.03 \\
0.08 \pm 0.03 \\
0.09 \pm 0.02^{\mathrm{a}}\end{array}$ & $\begin{array}{l}0.13 \pm 0.03 \\
0.06 \pm 0.02 \\
0.1 \pm 0.02^{\mathrm{a}} \\
\end{array}$ & $\begin{array}{l}0.09 \pm 0.01^{\mathrm{a}} \\
0.07 \pm 0.01^{\mathrm{a}}\end{array}$ \\
\hline & CVTCL & $\begin{array}{c}0-20 \\
20-40 \\
\text { Overall } \\
\end{array}$ & $\begin{array}{c}0.07 \pm 0.02 \\
0.06 \pm 0.01 \\
0.07 \pm 0.01^{\mathrm{b}} \\
\end{array}$ & $\begin{array}{c}0.07 \pm 0.01 \\
0.04 \pm 0.01 \\
0.05 \pm 0.01^{\mathrm{b}} \\
\end{array}$ & $\begin{array}{c}0.03 \pm 0.01 \\
0.03 \pm 0.01 \\
0.03 \pm 0.01^{\mathrm{b}} \\
\end{array}$ & $\begin{array}{l}0.05 \pm 0.01^{\mathrm{a}} \\
0.04 \pm 0.01^{\mathrm{a}}\end{array}$ \\
\hline & ECL & $\begin{array}{c}0-20 \\
20-40 \\
\text { Overall } \\
\end{array}$ & $\begin{array}{c}0.06 \pm 0.01 \\
0.05 \pm 0.01 \\
0.06 \pm 0.01^{\mathrm{b}} \\
\end{array}$ & $\begin{array}{c}0.05 \pm 0.01 \\
0.05 \pm 0.02 \\
0.05 \pm 0.01^{\mathrm{b}} \\
\end{array}$ & $\begin{array}{c}0.024 \pm 0.02 \\
0.06 \pm 0.03 \\
0.04 \pm 0.01^{\mathrm{b}} \\
\end{array}$ & $\begin{array}{l}0.05 \pm 0.01^{\mathrm{a}} \\
0.05 \pm 0.01^{\mathrm{a}}\end{array}$ \\
\hline \multirow{3}{*}{ CEC } & CTAFL & $\begin{array}{c}0-20 \\
20-40 \\
\text { Overall } \\
\end{array}$ & $\begin{array}{c}42.6 \pm 1.47 \\
43.93 \pm 1.35 \\
43.27 \pm 0.94^{\mathrm{a}}\end{array}$ & $\begin{array}{c}41.93 \pm 2.27 \\
43.6 \pm 1.51 \\
42.77 \pm 1.27^{\mathrm{a}}\end{array}$ & $\begin{array}{l}40.93 \pm 1.89 \\
39.27 \pm 2.89 \\
40.1 \pm 1.59^{\mathrm{a}} \\
\end{array}$ & $\begin{array}{l}41.82 \pm 0.98^{\mathrm{a}} \\
42.27 \pm 1.26^{\mathrm{a}}\end{array}$ \\
\hline & CVTCL & $\begin{array}{c}0-20 \\
20-40 \\
\text { Overall }\end{array}$ & $\begin{array}{c}30.4 \pm 9.5 \\
42.67 \pm 1.81 \\
36.53 \pm 5.12^{\mathrm{b}}\end{array}$ & $\begin{array}{c}40.8 \pm 2.69 \\
41.73 \pm 2.31 \\
41.27 \pm 1.59^{\mathrm{a}}\end{array}$ & $\begin{array}{c}31.4 \pm 7.4 \\
37.53 \pm 4.1 \\
34.47 \pm 4.01^{\mathrm{b}}\end{array}$ & $\begin{array}{l}34.20 \pm 3.92^{\mathrm{a}} \\
40.64 \pm 1.60^{\mathrm{a}}\end{array}$ \\
\hline & ECL & $\begin{array}{c}0-20 \\
20-40 \\
\text { Overall }\end{array}$ & $\begin{array}{c}41.07 \pm 1.68 \\
41.4 \pm 1.44 \\
41.23 \pm 0.9^{\mathrm{c}}\end{array}$ & $\begin{array}{c}39.73 \pm 2.76 \\
40.73 \pm 2.53 \\
40.23 \pm 1.69^{a}\end{array}$ & $\begin{array}{c}35.20 \pm 4.27 \\
36.6 \pm 1.61 \\
35.9 \pm 2.1^{\mathrm{b}}\end{array}$ & $\begin{array}{l}38.67 \pm 1.78^{\mathrm{a}} \\
39.58 \pm 1.22^{\mathrm{b}}\end{array}$ \\
\hline
\end{tabular}

Overall means followed by the same letter(s) across columns and rows are not significantly different $(\mathrm{p}=0.05)$ with respect to land slope, land use types and soil depth. CTAFL $=$ conservation tillage-based agroforestry land, $\mathrm{CVTCL}=$ conventional tillage-based cultivated land and $\mathrm{ECL}=$ enclosure-based communal land

Generally, soil under the CTAFL land use type has shown good performance in improving $\mathrm{pH}, \mathrm{EC}$ and CEC values. This was occurred due to higher addition of organic matter from agroforestry components coupled with higher clay contents in the land use. Clay is comprised of negatively charged particles that commonly absorb and hold positively charged ions and provides protection against depletion of nutrients through its colloidal aggregates. Maintaining and providing continuous flow of soil nutrients (nutrient recycling) as well as keeping the soil carbon for long periods is one of the main ecological contributions of CTAFL land use type (Cardinael et al., 2017; Ling et al., 2017; Pardon et al., 2017; Pereira et al., 2018), whereas rare cases of such a value were observed for the CVTCL land use type. Specifically, for the CVTCL land use type, depletion of basic cations due to tillage operation, precipitation of phosphorus due to rainfall (1200-1800 $\mathrm{mm}$ ) and high microbial oxidation that mostly produces organic acid probability have contributed to lower $\mathrm{pH}$ values in the soil. This result agrees with the findings of Ketema and Yimer (2014) and Negasa et al. (2017), who found lower pH values for cultivated lands compared with agroforestry land use types.

\section{Soil organic carbon (SOC \%) and total nitrogen (TN \%)}

Soil organic carbon (SOC \%) and total nitrogen (TN \%) were significantly affected by land use type $(\mathrm{p}<0.001)$ and soil depth $(\mathrm{p}=0.001$, Appendix 1$)$, respectively. Higher mean values of SOC and TN was obtained for CTAFL $(1.43 \%, 0.15 \%)$ compared to the ECL $(0.96 \%, 0.15 \%)$ and CVTCL $(0.67 \%, 0.14 \%)$ land use types (Table 9), respectively. The amount of SOC (\%) and TN (\%) from high to low was ranked as, CTAFL > ECL > CVTCL. Higher amounts of SOC and TN were obtained 
from the 0-20 cm soil layer, and they decreased as the depth increased. The higher SOC $(\%)$ in CTAFL land use was attributed to the agroforestry system of the area. Farmers have stayed friendly within the agroforestry system for a long period time (Kanshie, 2002; Kura, 2013). They usually cut and slash herbaceous weeds, branches of vertically stratified canopy of the agroforestry components and put on soil surface to use either as mulch or an input for soil fertility. In addition, the litter fall, dead plants/roots/macroorganisms and clay protection through aggregates (Bronick and Lal, 2005; Abu-hashim et al., 2016) have increased the SOC (\%) of the CTAFL land use type. Similarly, due to land rehabilitation and restoration processes on ECL, SOC (\%) and TN (\%) were found to be higher compared to the CVTCL land use type. However, due to frequent tillage practice, CVTCL had minimum SOC $(\%)$ and TN $(\%)$. Cultivation exposes available organic matter to moisture, aeration, and decomposing agents and facilitates fast mineralization (Comerford et al., 2013), thereby reducing the SOC and TN (Qi et al., 2018). Moreover, the local farmers do not leave crop residues on the soil after harvest; instead, they use it for animal feed and fuel wood sources. This has caused the soil to have low SOC (\%) and TN (\%) and to be vulnerable to erosion, weak and fragile in providing and maintaining ecological values or expected ecosystem services. Abuhashim et al. (2016) have presented similar findings, i.e., that soil disturbance is the main contributing factor minimizing the SOC (\%) in the soil.

Table 9. Soil organic carbon (SOC \%) and total nitrogen (TN \%) as indicators of the ecological values of land use types

\begin{tabular}{|c|c|c|c|c|c|c|}
\hline \multirow{2}{*}{ Variables } & \multirow{2}{*}{$\begin{array}{c}\text { Land use } \\
\text { types }\end{array}$} & \multirow{2}{*}{$\begin{array}{l}\text { Soil depth } \\
\quad \text { (cm) }\end{array}$} & \multicolumn{3}{|c|}{ Slope category } & \multirow{2}{*}{ Overall } \\
\hline & & & Upper & Middle & Lower & \\
\hline \multirow{9}{*}{ SOC (\%) } & \multirow{3}{*}{ CTAFL } & $0-20$ & $1.93 \pm 0.21$ & $1.77 \pm 0.1$ & $0.85 \pm 0.13$ & $1.52 \pm 0.18^{\mathrm{a}}$ \\
\hline & & $20-40$ & $1.69 \pm 0.48$ & $1.66 \pm 0.35$ & $0.65 \pm 0.08$ & $1.33 \pm 0.25^{\mathrm{b}}$ \\
\hline & & Overall & $1.81 \pm 0.24^{\mathrm{a}}$ & $1.72 \pm 0.17^{\mathrm{a}}$ & $0.75 \pm 0.08^{\mathrm{b}}$ & \\
\hline & \multirow{3}{*}{ CVTCL } & $0-20$ & $0.95 \pm 0.01$ & $0.82 \pm 0.17$ & $0.58 \pm 0.05$ & $0.78 \pm 0.2^{\mathrm{a}}$ \\
\hline & & $20-40$ & $0.65 \pm 0.20$ & $0.47 \pm 0.1$ & $0.56 \pm 0.06$ & $0.56 \pm 0.21^{\mathrm{a}}$ \\
\hline & & Overall & $0.8 \pm 0.16^{\mathrm{b}}$ & $0.65 \pm 0.01^{\mathrm{b}}$ & $0.57 \pm 0.03^{\mathrm{c}}$ & \\
\hline & \multirow{3}{*}{ ECL } & $0-20$ & $1.35 \pm 0.17$ & $1.20 \pm 0.19$ & $0.72 \pm 0.16$ & $1.09 \pm 0.18^{\mathrm{a}}$ \\
\hline & & $20-40$ & $1.11 \pm 0.08$ & $0.87 \pm 0.11$ & $0.50 \pm 0.09$ & $0.83 \pm 0.24^{b}$ \\
\hline & & Overall & $1.23 \pm 0.97^{\mathrm{c}}$ & $1.04 \pm 0.12^{\mathrm{c}}$ & $0.61 \pm 0.95^{\mathrm{a}}$ & \\
\hline \multirow{9}{*}{$\mathrm{TN}(\%)$} & \multirow{3}{*}{ CTAFL } & $0-20$ & $0.18 \pm 0.04$ & $0.11 \pm 0.03$ & $0.13 \pm 0.04$ & $0.14 \pm 0.02^{\mathrm{a}}$ \\
\hline & & $20-40$ & $0.15 \pm 0.01$ & $0.18 \pm 0.02$ & $0.13 \pm 0.03$ & $0.15 \pm 0.01^{b}$ \\
\hline & & Overall & $0.17 \pm 0.02^{\mathrm{a}}$ & $0.14 \pm 0.02^{\mathrm{a}}$ & $0.13 \pm 0.02^{\mathrm{a}}$ & \\
\hline & \multirow{3}{*}{ CVTCL } & $0-20$ & $0.16 \pm 0.01$ & $0.13 \pm 0.03$ & $0.17 \pm 0.03$ & $0.15 \pm 0.01^{\mathrm{a}}$ \\
\hline & & $20-40$ & $0.13 \pm 0.02$ & $0.11 \pm 0.01$ & $0.15 \pm 0.04$ & $0.13 \pm 0.01^{b}$ \\
\hline & & Overall & $0.15 \pm 0.01^{\mathrm{ab}}$ & $0.12 \pm 0.01^{\mathrm{ab}}$ & $0.15 \pm 0.02^{\mathrm{ab}}$ & \\
\hline & \multirow{3}{*}{ ECL } & $0-20$ & $0.16 \pm 0.02$ & $0.12 \pm 0.02$ & $0.18 \pm 0.02$ & $0.15 \pm 0.01^{\mathrm{a}}$ \\
\hline & & $20-40$ & $0.16 \pm 0.03$ & $0.11 \pm 0.06$ & $0.16 \pm 0.03$ & $0.15 \pm 0.02^{\mathrm{a}}$ \\
\hline & & Overall & $0.16 \pm 0.02^{\mathrm{a}}$ & $0.12 \pm 0.03^{\mathrm{a}}$ & $0.17 \pm 0.03^{\mathrm{a}}$ & \\
\hline
\end{tabular}

Overall means followed by the same letter(s) across columns and rows are not significantly different $(\mathrm{p}=0.05)$ with respect to land slope, land use types and soil depth. CTAFL $=$ conservation tillage-based agroforestry land, CVTCL = conventional tillage-based cultivated land and ECL = enclosure-based communal land 
Soil biological properties as an indicator: soil macro-organisms observable by the naked eye (NSMOE)

Soil macro-organisms observable by naked eye were significantly influenced by land use types $(\mathrm{p}<0.001)$ and soil depth $(\mathrm{p}<0.001$, Appendix 1$)$. A higher number of soil macro-organisms were observed on CTAFL $(\approx 33)$ compared to ECL $(\approx 18)$ and CVTCL $(\approx 12)$ land use types (Table 10$)$. A higher number of NSMOE was found at 0 $20 \mathrm{~cm}$, and their number decreased as the depth increased. The higher availability of macro-organisms on the top surface of CTAFL is directly related with the higher availability of soil organic matter (Negasa et al., 2017). Their number decreased at depths of $20-40 \mathrm{~cm}$ due to the lower availability of soil organic matter and soil compaction caused by the overlaying mass of soil. Different studies (Lavelle et al., 2006; Barrios, 2007; Pereira et al., 2018; Ren et al., 2018) have shown that a high amount of plant residue (herbaceous weeds, litter fall, crop residues after harvest and dead roots) inputs is able to create a conducive environment for an increased number of macro-organisms in the soil. However, on CVTCL, their number was far lower than for the CTAFL and ECL land use types. This occurred most likely due to the presence of continuous soil disturbance (Ketema and Yimer, 2014; Negasa et al., 2017). Lavelle et al. (2006) stated that soil disturbance could profoundly affect the number and types of macro-organisms observable by the naked eye in the soil.

Table 10. Number of soil macro-organisms observed by the naked eye (NSMOE) as an indicator of the ecological values of land use types

\begin{tabular}{|c|c|c|c|c|c|c|}
\hline \multirow{2}{*}{ Variables } & \multirow{2}{*}{ Land use types } & \multirow{2}{*}{$\begin{array}{l}\text { Soil depth } \\
\quad(\mathrm{cm})\end{array}$} & \multicolumn{3}{|c|}{ Land slope } & \multirow{2}{*}{ Overall } \\
\hline & & & Upper & Middle & Lower & \\
\hline \multirow{9}{*}{ NSMOE } & \multirow{3}{*}{ CTAFL } & $0-20$ & $39.1 \pm 7.81$ & $46.7 \pm 12.01$ & $46.00 \pm 2.1$ & $43.89 \pm 4.36^{\mathrm{a}}$ \\
\hline & & $20-40$ & $18.7 \pm 4.1$ & $20.00 \pm 9.29$ & $22.67 \pm 6.4$ & $20.44 \pm 3.5^{\mathrm{b}}$ \\
\hline & & Overall & $28.83 \pm 6.01^{\mathrm{a}}$ & $33.33 \pm 9.03^{\mathrm{a}}$ & $34.33 \pm 6.01^{\mathrm{a}}$ & \\
\hline & \multirow{3}{*}{$\mathrm{ECL}$} & $0-20$ & $15.33 \pm 4.5$ & $23.33 \pm 4.4$ & $42.00 \pm 20.5$ & $26.89 \pm 7.35^{\mathrm{a}}$ \\
\hline & & $20-40$ & $6.67 \pm 0.9$ & $12.67 \pm 6.5$ & $2.33 \pm 0.9$ & $7.22 \pm 2.42^{b}$ \\
\hline & & Overall & $11.00 \pm 2.81^{\mathrm{b}}$ & $18.00 \pm 4.24^{\mathrm{b}}$ & $22.17 \pm 12.78^{b}$ & \\
\hline & \multirow{3}{*}{ CVTCL } & $0-20$ & $17.01 \pm 8.02$ & $30.01 \pm 5.8$ & $4.33 \pm 1.45$ & $17.11 \pm 4.69^{\mathrm{a}}$ \\
\hline & & $20-40$ & $1.33 \pm 0.33$ & $10.00 \pm 2.90$ & $3.67 \pm 0.67$ & $5.02 \pm 1.55^{b}$ \\
\hline & & Overall & $9.17 \pm 5.01^{\mathrm{c}}$ & $20.03 \pm 5.32^{c}$ & $4.05 \pm 0.73^{c}$ & \\
\hline
\end{tabular}

Overall means followed by the same letter(s) across columns and rows are not significantly different $(\mathrm{p}=0.05)$ with respect to land slope, land use types and soil depth. CTAFL = conservation tillage-based agroforestry land, CVTCL = conventional tillage-based cultivated land and ECL = enclosure-based communal land

\section{Farmers' assessment vs. soil empirical analysis of ecological values land use types}

The sustainability of ecological values of land use types is closely related to successful land use management (Andruschkewitsch et al., 2013; Bogunovic et al., 2018; Peigné et al., 2018; Wang et al., 2018). Land management either positively or negatively influences the soil (Bogunovic et al., 2018), the environment and ecological processes above and beneath the soil (Table 11) leading to remarkable changes in soil properties. In the study area, farmers have a strong stake in managing the land use types (CTAFL, ECL \& CVTCL), and their active participation would have strong influence 
on land use decision-making (Duguma and Hager, 2011). CTAFL land use management has been reported to improve ecological values of land use types and soil properties (Kanshie, 2002; Leye, 2007; Habtamu, 2011; Kura, 2013). Nearly all individual farmers in the study area chose the CTAFL land use type as the best land use type followed by ECL, whereas CVTCL had the lowest preference (CTAFL> ECL>CVTCL) (Fig. 6A, $B)$. CTAFL has a strong contribution for minimizing soil erosion (Wang et al., 2018), improving water availability, soil infiltration, soil fertility (Andruschkewitsch et al., 2013; Ochoa et al., 2016), animal feed and micro-climate of the area. Figure $6 a$, $b$ has shown the mean score values of the three land use types (LUT) and higher mean score has been obtained from CTAFL relative to ECL and CVTCL land use types. On the other hand, the empirical analysis of the soil has also indicated a higher amount of ECE, EC, SOC (\%), TN (\%), water infiltration, NSMOE, Pt (\%) and SMC soil properties on CTAFL relative to ECL and CVTCL land use types (CTAFL>ECL>CVTCL). Therefore, the farmers' assessment result was supported parallelly by the empirical analysis of the soil. Figure $6 a, b$ illustrates these realities.
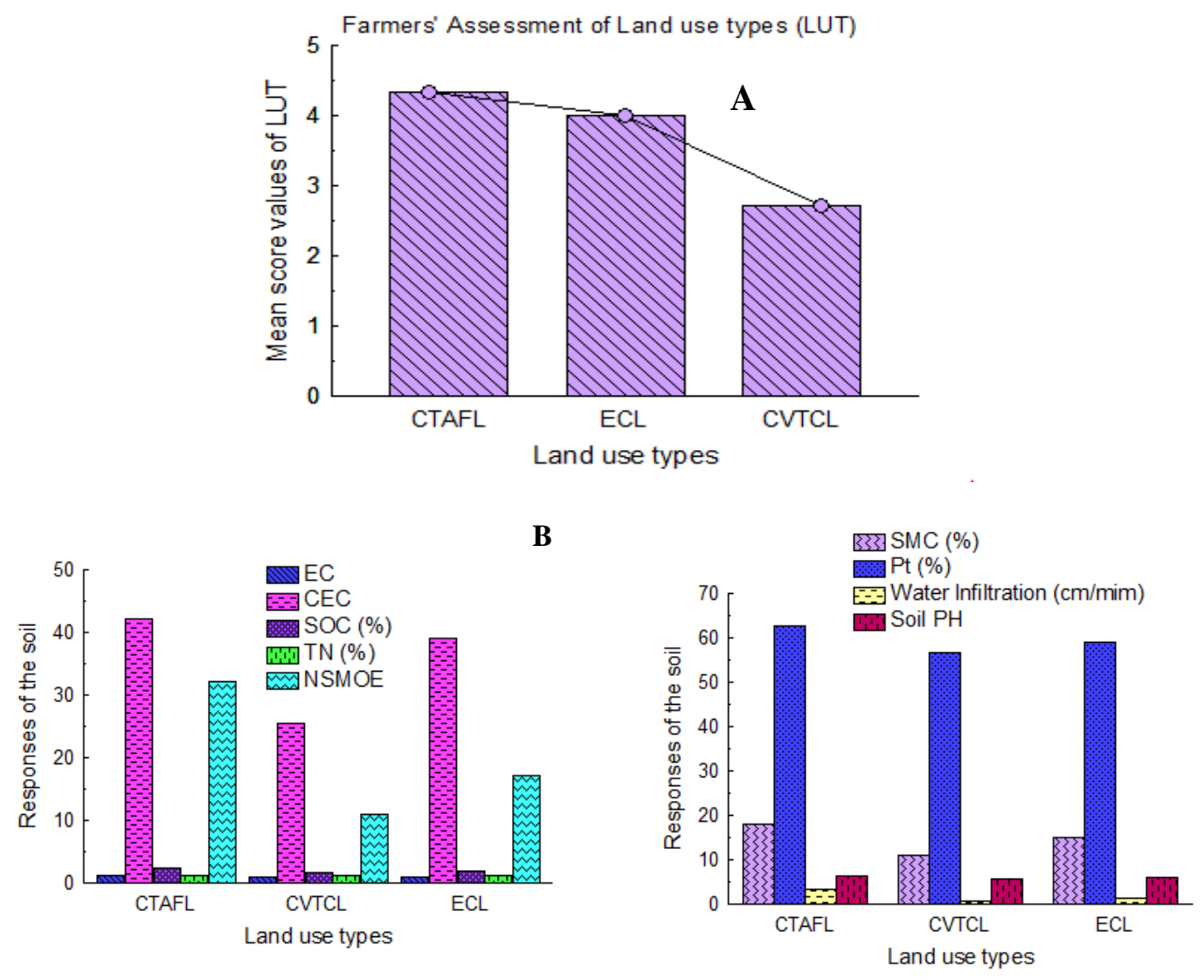

Figure 6. Farmers' assessment (a) vs. empirical soil analysis (b) results of land use type

Ecological values or ecosystem services such as water flow regulation, carbon sequestration (high SOC in CTAFL), nutrient cycling, maintaining soil moisture, aeration, allowing root penetration, soil erosion control, soil fertility improvement and refuge for soil macro-organisms were the most essential advantages obtained from the conservation tillage-based agroforestry land use type (Negasa et al., 2017; Bogunovic et 
al., 2018; Peigné et al., 2018; Pereira et al., 2018; Wang et al., 2018). The smaller bulk density available on CTAFL positively contributed to the higher infiltration rate of water into the soil. Springs and other water sources observed (researchers observation) on the lower slope of the land in the study area were due to water infiltration held at the upper area of the CTAFL land use type.

Table 11. Soil as an indicator of a land use type's ecological values/ecosystem service

\begin{tabular}{|c|c|c|c|c|}
\hline $\begin{array}{c}\text { Soil } \\
\text { variables }\end{array}$ & Indicators & $\begin{array}{l}\text { Relevance to soil } \\
\text { function }\end{array}$ & $\begin{array}{c}\text { Contribution to } \mathrm{LUT} \\
\text { ecological values }\end{array}$ & Reference \\
\hline \multirow{3}{*}{$\begin{array}{l}\text { Physical } \\
\text { variable }\end{array}$} & $\begin{array}{l}\text { Soil bulk } \\
\text { density }\end{array}$ & \begin{tabular}{|} 
Root penetration, porosity, \\
gas exchange, soil \\
erodibility, water \& \\
organism movement, \\
organic matter \& nutrient \\
retention
\end{tabular} & $\begin{array}{c}\text { Biomass production, climate } \\
\text { regulation, soil } \\
\text { development/conservation, } \\
\text { nutrient cycling }\end{array}$ & \multirow{3}{*}{$\begin{array}{l}\text { Lavelle et al., 2006; } \\
\text { Comerford et al., } \\
\text { 2013; Costantini, } \\
\text { 2016; Negasa et al., } \\
\text { 2017; Pereira et al., } \\
2018\end{array}$} \\
\hline & $\begin{array}{l}\text { Infiltration } \\
\text { capacity }\end{array}$ & $\begin{array}{c}\text { Run-off/erosion control, } \\
\text { Leaching, Sedimentation, } \\
\text { Siltation control }\end{array}$ & $\begin{array}{l}\text { Soil development, water } \\
\text { purification \& regulation, } \\
\text { flood mitigation, } \mathrm{CO}_{2} \\
\text { emission, contamination } \\
\text { regulation }\end{array}$ & \\
\hline & $\begin{array}{l}\text { Water } \\
\text { holding } \\
\text { capacity }\end{array}$ & $\begin{array}{c}\text { Retention and } \\
\text { transportation of water and } \\
\text { chemicals }\end{array}$ & \begin{tabular}{|} 
Water purification \& \\
regulation, food and fiber \\
production, biomass \\
production, soil development \\
\end{tabular} & \\
\hline \multirow{4}{*}{$\begin{array}{l}\text { Chemical } \\
\text { variables }\end{array}$} & OM (SOC) & $\begin{array}{c}\text { Soil fertility and structure, } \\
\text { soil aggregate and fauna, } \\
\text { water retention }\end{array}$ & $\begin{array}{c}\text { Carbon sequestration, soil } \\
\text { development/conservation, } \\
\text { nutrient cycling, biomass } \\
\text { production, water purification } \\
\& \text { regulation }\end{array}$ & \multirow{4}{*}{$\begin{array}{l}\text { Lavelle et al., 2006; } \\
\text { Comerford et al., } \\
\text { 2013; Costantini, } \\
\text { 2016; Negasa et al., } \\
\text { 2017; Pereira et al., } \\
2018\end{array}$} \\
\hline & $\mathrm{pH}$ & $\begin{array}{c}\text { Nutrient availability, } \\
\text { mobility, soil organisms }\end{array}$ & $\begin{array}{c}\text { Biomass production, nutrient } \\
\text { cycling }\end{array}$ & \\
\hline & CEC & $\begin{array}{c}\text { Soil nutrient, plant growth, } \\
\text { water infiltration, soil } \\
\text { structure }\end{array}$ & $\begin{array}{l}\text { Food and fiber production, } \\
\text { nutrient cycling }\end{array}$ & \\
\hline & $\mathrm{EC}$ & $\begin{array}{c}\text { Soil water potential, } \\
\text { salinity }\end{array}$ & $\begin{array}{l}\text { Water purification, water } \\
\text { regulation }\end{array}$ & \\
\hline $\begin{array}{l}\text { Biological } \\
\text { variables }\end{array}$ & NSMOE & $\begin{array}{l}\text { Control erosion, surface } \\
\text { run-off, OM } \\
\text { decomposition, water } \\
\text { retention, gas and water } \\
\text { circulation, structural } \\
\text { porosity }\end{array}$ & $\begin{array}{l}\text { Flood mitigation, gas and } \\
\text { water circulation, nutrient } \\
\text { cycling, climate regulation, } \\
\text { soil formation, primary } \\
\text { production }\end{array}$ & $\begin{array}{l}\text { Lavelle et al., 2006; } \\
\text { Comerford et al., } \\
\text { 2013; Pascual et al., } \\
\text { 2015; Negasa et al., } \\
2017\end{array}$ \\
\hline
\end{tabular}

NSMOE = number of soil macro-organisms observed by the naked eye, $\mathrm{CEC}=$ cation exchange capacity, $\mathrm{pH}=$ soil reaction, $\mathrm{OM}(\mathrm{SOC})=$ organic matter/soil organic carbon, $\mathrm{EC}=$ soil electrical conductivity, LUT = land use type

The portion of the rainfall reaching the soil was controlled by infiltration and water storage characteristics of the soil (Comerford et al., 2013). The more rainfall that infiltrates into the soil, the less run-off is created. Farmers exhibited the least preference (except for animal feed source role) for the conventional tillage-based cultivated 
(CVTCL) land use type. The role played by the land use in controlling soil erosion, soil fertility, water infiltration and micro-climate improvement was less compared to CTAFL. Previous studies (Kura, 2013; Peigné et al., 2018; Bogunovic et al., 2018; Wang et al., 2018; Pereira et al., 2018) have explained that land use with conventional tillage management has less contribution to the improvement of land use ecological values compared to conservation-based management.

\section{Conclusion and recommendation}

The quantification of ecological values of land use type aims at providing valuable information about the performance of the land use that can be used to support land use management decision-making processes. Based on farmers' assessments and empirical soil property analysis, conservation tillage-based agroforestry land (CTAFL) was the best land use type, possessing higher ecological values (such as minimizing soil erosion, improving water availability and infiltration, feed source for animals, soil fertility and micro-climate improvement) compared with the enclosure-based communal land (ECL) and conventional tillage-based cultivated land (CVTCL) land use types. CVTCL was the least-preferred land use type by farmers due to its lower contribution for improvements of ecological values. Based on this research, ECL was not selected as the best land use type most likely due to its being common property that mostly limits the right of individuals (only allowing group use) to use the available resources from the land use type. Moreover, lack of equity and good administration were also the main causes for the farmers to not select ECL as the best land use type in the study area.

Since ECL land use is a closure area that protects interference, the local farmers have felt and sensed the ecological values or ecosystem services improvements that have been made so far in the area. Due to many years of accumulated local knowledge, farmers had a detailed understanding of the ecological values of their land use types, as evidenced by this research. Their qualitative explanations and justifications are mostly compatible with currently available scientific evidence derived from empirically analyzed soil physical, chemical and biological properties. Based on this fact, the following conclusions were drawn from the soil analysis that was manifested the ecological values/ecosystem services of land use types in the study area.

As was clearly shown, the soil textural fraction (sand, silt and clay), bulk density, soil moisture content (SMC \%), water infiltration, soil pH, EC, CEC, soil organic carbon (SOC \%), total nitrogen (TN \%) and number of macro-organism observed by the naked eye (NSMOE) significantly varied between land use type and soil depth. Clay was the dominant textural fraction, which accounts more than $50 \%$ of the soil volume, indicating the accumulation of old and weathered soil in the area. Higher clay content was observed on CTAFL compared with the other land use type. Moreover, except for bulk density, higher water infiltration, soil pH values, EC, CEC, SOC (\%), TN (\%) and NSMOE were observed on CTAFL, while they were low in CVTCL (high bulk density) and ECL land use types. These higher values on CTAFL were connected with the availability of higher soil organic matter and its protection by the clay textural fraction of the soil. However, soil disturbance is the main factor that diminishes the ecological values of CVTCL land use type.

Finally, it is good to continuously blend and rely on both farmers' knowledge and the scientific experiment (soil analysis) for quantifying and evaluating the ecological values/ecosystem service of the land use types before applying land use management decisions. This enhances the collaboration between local communities and the 
scientists. This in turn enhances the efficiency of land use management activities and reduces the disconnect that often occurred between local community and the researchers.

Acknowledgements. We are grateful for willingness of local farmers who allowed us to carry out interview and group discussion and conduct our research on their farms. We also extend our thanks for assistance from Ministry of Agriculture and Rural Development Office at Woreda level and Development Agents at Kebele level for data collection. Finally, the authors are indebted to thank the National Natural Science Foundation of China (Fund No. 41571176), International Cooperation and Cultivation Project of Nanjing Agricultural University (Fund No. 2018-AF-22), and The 111 Project (Fund No.B17024) by State Administration of Foreign Experts Affairs and Ministry of Education of China for Financial support.

\section{REFERENCES}

[1] Abu-Hashim, M., Elsayed, M., Belal, A.-E. (2016): Effect of land-use changes and site variables on surface soil organic carbon pool at Mediterranean Region. - Journal of African Earth Sciences 114: 78-84.

[2] Adhikari, K., Hartemink, A. E. (2016): Linking soils to ecosystem services-A global review. - Geoderma 262: 101-111.

[3] Alemayehu, M., Amede, T., Böhme, M., Peters, K. (2013): Collective management on communal grazing lands: Its impact on vegetation attributes and soil erosion in the upper Blue Nile basin, northwestern Ethiopia. - Livestock Science 157: 271-279.

[4] Andruschkewitsch, R., Geisseler, D., Koch, H.-J., Ludwig, B. (2013): Effects of tillage on contents of organic carbon, nitrogen, water-stable aggregates and light fraction for four different long-term trials. - Geoderma 192: 368-377.

[5] Araujo, A. S. F., Leite, L. F. C., De Freitas Iwata, B., De Andrade Lira, M., Xavier, G. R., Figueiredo, M. D. V. B. (2012): Microbiological process in agroforestry systems. A review. - Agronomy for Sustainable Development 32: 215-226.

[6] Bagyaraj, D., Thilagar, G., Ravisha, C., Kushalappa, C. G., Krishnamurthy, K., Vaast, P. (2015): Below ground microbial diversity as influenced by coffee agroforestry systems in the Western Ghats, India. - Agriculture, Ecosystems \& Environment 202: 198-202.

[7] Barrios, E. (2007): Soil biota, ecosystem services and land productivity. - Ecological Economics 64: 269-285.

[8] Bertrand, A. R. (1965): Rate of Water Intake in the Field. - In: Black, C. A. (ed.) Methods of Soil Analysis, Part I Physical and Mineralogical Properties, Including Statistics of Measurement and Sampling. American Society of Agronomy, Madison, Wisconsin, USA 197-209.

[9] Bewket, W., Sterk, G. (2003): Assessment of soil erosion in cultivated fields using a survey methodology for rills in the Chemoga watershed, Ethiopia. - Agriculture, Ecosystems \& Environment 97: 81-93.

[10] Bogunovic, I., Pereira, P., Kisic, I., Sajko, K., Sraka, M. (2018): Tillage management impacts on soil compaction, erosion and crop yield in Stagnosols (Croatia). - Catena 160: 376-384.

[11] Braimoh, A. K., Vlek, P. L. (2008): Impact of Land Use on Soil Resources. - In: Braimoh, A. K., Vlek, P. L. G. (eds.) Land Use and Soil Resources. Springer, Dordrecht, pp. 1-7.

[12] Bremner, J., Mulvaney, C. (1982): Nitrogen-Total. - In: Page, A. L., et al. (eds.) Methods of Soil Analysis. Part 2: Chemical and Microbial Properties (2nd edn.), Agronomy No. 9. American Society of Agronomy, Madison, Wisconsin, USA, pp. 595-624. 
[13] Breure, A. M., De Deyn, G. B., Dominati, E., Eglin, T., Hedlund, K., Van Orshoven, J., Posthuma, L. (2012): Ecosystem services: a useful concept for soil policy making! Current Opinion in Environmental Sustainability 4: 578-585.

[14] Bronick, C. J., Lal, R. (2005): Soil structure and management: a review. - Geoderma 124: 3-22.

[15] Cardinael, R., Chevallier, T., Cambou, A., Béral, C., Barthès, B. G., Dupraz, C., Durand, C., Kouakoua, E., Chenu, C. (2017): Increased soil organic carbon stocks under agroforestry: a survey of six different sites in France. - Agriculture, Ecosystems \& Environment 236: 243-255.

[16] Cerretelli, S., Poggio, L., Gimona, A., Yakob, G., Boke, S., Habte, M., Coull, M., Peressotti, A., Black, H. (2018): Spatial assessment of land degradation through key ecosystem services: The role of globally available data. - Science of the Total Environment 628: 539-555.

[17] Comerford, N. B., Franzluebbers, A. J., Stromberger, M. E., Morris, L., Markewitz, D., Moore, R. (2013): Assessment and evaluation of soil ecosystem services. - Soil Horizons 54: $1-14$.

[18] Costantini, E. A. (2016): Soil indicators to assess the effectiveness of restoration strategies in dryland ecosystems. - Solid Earth 7: 397.

[19] Costanza, R., Farber, S., Liu, S., Troy, A. (2010): Valuing Ecosystem Services. Theory, Practice, and the Need for a Transdisciplinary Synthesis. - Gund Institute of Ecological Economics and Rubenstein School of Environment and Natural Resources, University of Vermont, Burlington, Vermont, USA.

[20] Cuenca, R. H. (1989): Irrigation System Design. An Engineering Approach. - Prentice Hall, Inc., Englewood Cliffs, New Jersey.

[21] De Groot, R., Brander, L., Van Der Ploeg, S., Costanza, R., Bernard, F., Braat, L., Christie, M., Crossman, N., Ghermandi, A., Hein, L. (2012): Global estimates of the value of ecosystems and their services in monetary units. - Ecosystem Services 1: 50-61.

[22] De Groot, R. S., Wilson, M. A., Boumans, R. M. (2002): A typology for the classification, description and valuation of ecosystem functions, goods and services. Ecological Economics 41: 393-408.

[23] De Sosa, L. L., Glanville, H. C., Marshall, M. R., Williams, A. P., Jones, D. L. (2018): Quantifying the contribution of riparian soils to the provision of ecosystem services. Science of the Total Environment 624: 807-819.

[24] Deru, J. G., Bloem, J., De Goede, R., Keidel, H., Kloen, H., Rutgers, M., Van Den Akker, J., Brussaard, L., Van Eekeren, N. (2017): Soil ecology and ecosystem services of dairy and semi-natural grasslands on peat. - Appl. Soil Ecol. 125: 26-34.

[25] Dominati, E., Patterson, M., Mackay, A. (2010): A framework for classifying and quantifying the natural capital and ecosystem services of soils. - Ecological Economics 69: 1858-1868.

[26] Duguma, L. A., Hager, H. (2011): Farmers' assessment of the social and ecological values of land uses in central Highland Ethiopia. - Environmental Management 47: 969982.

[27] Duncan, A. J., Bachewe, F., Mekonnen, K., Valbuena, D., Rachier, G., Lule, D., Bahta, M., Erenstein, O. (2016): Crop residue allocation to livestock feed, soil improvement and other uses along a productivity gradient in Eastern Africa. - Agriculture, Ecosystems \& Environment 228: 101-110.

[28] Feng, Y., He, C., Yang, Q., He, J. (2014): Evaluation of ecological effect in land use planning using ecosystem service value method. - Transactions of the Chinese Society of Agricultural Engineering 30: 201-211.

[29] Franzel, S., Hitimana, L., Akyeampong, E. (1995): Farmer participation in on-station tree species selection for agroforestry: a case study from Burundi. - Experimental Agriculture 31: 27-38. 
[30] Gebregziabher, S., Mouazen, A. M., Van Brussel, H., Ramon, H., Nyssen, J., Verplancke, H., Behailu, M., Deckers, J., De Baerdemaeker, J. (2006): Animal drawn tillage, the Ethiopian ard plough, maresha: A review. - Soil \& Tillage Research 89: 129-143.

[31] Geneletti, D. (2006): Ecological evaluation of land: some considerations on approaches and shortcomings. - International Journal of Sustainable Development and Planning 1: 419-428.

[32] Greiner, L., Keller, A., Grêt-Regamey, A., Papritz, A. (2017): Soil function assessment: review of methods for quantifying the contributions of soils to ecosystem services. Land Use Policy 69: 224-237.

[33] Habtamu, T. (2011): Assessment of sustainable watershed management approach case study lenche dima, tsegur eyesus and dijjil watershed. - MSc Thesis, Cornell University, USA.

[34] Hillel, D. (2004): Introduction to Environmental Soil Physics. - Elsevier Acad., Amsterdam.

[35] Itanna, F., Olsson, M., Stahr, K. (2011): Effect of land use changes on soil carbon status of some soil types in the Ethiopian Rift Valley. - Journal of the Drylands 4: 289-299.

[36] Kanshie, T. (2002): Five thousand years of sustainability? A case study on Gedeo land use (Southern Ethiopia). - Ph.D. Dissertation, Wageningen Agricultural University, Wageningen.

[37] Ketema, H., Yimer, F. (2014): Soil property variation under agroforestry based conservation tillage and maize based conventional tillage in Southern Ethiopia. - Soil \& Tillage Research 141: 25-31.

[38] Kura, A. L. (2013): The dynamics of indigenous knowledge pertaining to agroforestry systems of Gedeo and its implications for sustainability. - Ph.D Dessertation, UNISA, Adelaide.

[39] Lal, R. (2003): Soil erosion and the global carbon budget. - Environment International 29: 437-450.

[40] Lavelle, P., Decaëns, T., Aubert, M., Barot, S., Blouin, M., Bureau, F., Margerie, P., Mora, P., Rossi, J.-P. (2006): Soil invertebrates and ecosystem services. - European Journal of Soil Biology 42: S3-S15.

[41] Leemans, R., De Groot, R. (2003): Millennium Ecosystem Assessment: Ecosystems and human well-being: a framework for assessment. - Island Press, Washington, DC.

[42] Leye, M. T. (2007): Conservation Tillage Systems and Water Productivity-Implications for Smallholder Farmers in Semi-arid Ethiopia. - Ph.D Thesis, UNESCO-IHE Institute for Water Education. CRC Press, Delft, The Netherlands.

[43] Ling, Q., Gao, X., Zhao, X., Huang, J., Li, H., Li, L., Sun, W., Wu, P. (2017): Soil water effects of agroforestry in rainfed jujube (Ziziphus jujube Mill.) orchards on loess hillslopes in Northwest China. - Agriculture, Ecosystems \& Environment 247: 343-351.

[44] Liu, Y., Huang, X., Yang, H., Zhong, T. (2014): Environmental effects of land-use/cover change caused by urbanization and policies in Southwest China Karst area-A case study of Guiyang. - Habitat International 44: 339-348.

[45] Liu, Z., Ma, D., Hu, W., Li, X. (2018): Land use dependent variation of soil water infiltration characteristics and their scale-specific controls. - Soil \& Tillage Research 178: 139-149.

[46] Mafongoya, P. L., Kuntashula, E. (2005): Participatory evaluation of Tephrosia species and provenances for soil fertility improvement and other uses using farmer criteria in eastern Zambia. - Experimental Agriculture 41: 69-80.

[47] Mazengia, W., Gamiyo, D., Amede, T., Daka, M., Mowo, J. (2007): Challenges of collective action in soil and water conservation: The case of Gununo Watershed, Southern Ethiopia. - African Crop Science Conference 8: 1541-1545.

[48] MEA (2005): Ecosystems and Human Well-Being: Synthesis. - Island Press, Washington, DC. 
[49] Negasa, T., Ketema, H., Legesse, A., Sisay, M., Temesgen, H. (2017): Variation in soil properties under different land use types managed by smallholder farmers along the toposequence in southern Ethiopia. - Geoderma 290: 40-50.

[50] Negash, M., Kanninen, M. (2015): Modeling biomass and soil carbon sequestration of indigenous agroforestry systems using CO2FIX approach. - Agriculture, Ecosystems \& Environment 203: 147-155.

[51] Ochoa, P. A., Fries, A., Mejía, D., Burneo, J. I., Ruíz-Sinoga, J. D., Cerdà, A. (2016): Effects of climate, land cover and topography on soil erosion risk in a semiarid basin of the Andes. - Catena 140: 31-42.

[52] Oguike, P., Mbagwu, J. (2009): Variations in some physical properties and organic matter content of soils of coastal plain sand under different land use types. - World Journal of Agricultural Sciences 5(1): 63-69.

[53] Oicha, T., Cornelis, W., Verplancke, H., Nyssen, J., Govaerts, B., Behailu, M., Haile, M., Deckers, J. (2010): Short-term effects of conservation tillage on soil (Vertisol) and crop (teff, Eragrostis tef) attributes in the orthern Ethiopian highlands. - Proceedings of the 19th World Congress of Soil Science, Soil Solutions for a Changing World, Brisbane, pp. 149-152.

[54] Pardon, P., Reubens, B., Reheul, D., Mertens, J., De Frenne, P., Coussement, T., Janssens, P., Verheyen, K. (2017): Trees increase soil organic carbon and nutrient availability in temperate agroforestry systems. - Agriculture, Ecosystems \& Environment 247: 98-111.

[55] Pascual, U., Termansen, M., Hedlund, K., Brussaard, L., Faber, J. H., Foudi, S., Lemanceau, P., Jørgensen, S. L. (2015): On the value of soil biodiversity and ecosystem services. - Ecosystem Service 15: 11-18.

[56] Peigné, J., Vian, J.-F., Payet, V., Saby, N. P. A. (2018): Soil fertility after 10 years of conservation tillage in organic farming. - Soil \& Tillage Research 175: 194-204.

[57] Pereira, P., Bogunovic, I., Muñoz-Rojas, M., Brevik, E. C. (2018): Soil ecosystem services, sustainability, valuation and management. - Current Opinion in Environmental Science \& Health 5: 7-13.

[58] Qi, Y., Chen, T., Pu, J., Yang, F., Shukla, M. K., Chang, Q. (2018): Response of soil physical, chemical and microbial biomass properties to land use changes in fixed desertified land. - Catena 160: 339-344.

[59] Ren, C., Wang, T., Xu, Y., Deng, J., Zhao, F., Yang, G., Han, X., Feng, Y., Ren, G. (2018): Differential soil microbial community responses to the linkage of soil organic carbon fractions with respiration across land-use changes. - Forest Ecology and Management 409: 170-178.

[60] Schnitzer, M. (1982): Total Carbon, Organic Matter, and Carbon. - In: Page, A. L., et al. (eds.) Methods of Soil Analysis. Part 2: Chemical and Microbial Properties (2nd edn.), Agronomy No. 9. American Society of Agronomy, Madison, Wisconsin, USA, pp. 539577.

[61] Tefera, M., Demel, T., Hultén, H., Yemshaw, Y. (2005): The role of communities in closed area management in Ethiopia. - Mountain Research and Development 25: 44-50.

[62] Temesgen, H., Wu, W. (2018): Farmers' value assessment of sociocultural and ecological ecosystem services in agricultural landscapes. - Sustainability 10: 703.

[63] Temesgen, H., Wu, W., Eshetu, Y., Belewu, B., Mengistie, K. (2018a): Variation in ecosystem service values in an agroforestry dominated landscape in Ethiopia: implications for land use and conservation policy. - Sustainability 10: 1126.

[64] Temesgen, H., Wu, W., Legesse, A., Yirsaw, E., Bekele, B. (2018b): Landscape-based upstream-downstream prevalence of land-use/cover change drivers in southeastern rift escarpment of Ethiopia. - Environmental Monitoring and Assessment 190: 166.

[65] USDA (1972): Soil Survey Laboratory Methods and Procedures for Collecting Soil Samples. - Soil Conservation Service, USDA, Washington. 
[66] Wade, M. R., Gurr, G. M., Wratten, S. D. (2008): Ecological restoration of farmland: progress and prospects. - Philosophical Transactions of the Royal Society of London Series B 363: 831-847.

[67] Wang, Y., Fan, J., Cao, L., Zheng, X., Ren, P., Zhao, S. (2018): The influence of tillage practices on soil detachment in the red soil region of China. - Catena 165: 272-278.

[68] Zake, J., Pietsch, S. A., Friedel, J. K., Zechmeister-Boltenstern, S. (2015): Can agroforestry improve soil fertility and carbon storage in smallholder banana farming systems? - Journal of Plant Nutrition and Soil Science 178: 237-249.

\section{APPENDIX}

Summary of ANOVA table

\begin{tabular}{|c|c|c|c|c|c|c|c|c|c|c|c|c|c|c|c|c|c|}
\hline \multirow{3}{*}{$\begin{array}{l}\text { Source of } \\
\text { variation }\end{array}$} & \multirow{3}{*}{ df } & \multicolumn{16}{|c|}{ Soil parameters } \\
\hline & & \multicolumn{2}{|r|}{ BD } & \multicolumn{2}{|r|}{ pH } & \multicolumn{2}{|c|}{ EC } & \multicolumn{2}{|c|}{ TN } & \multicolumn{2}{|c|}{ CEC } & \multicolumn{2}{|c|}{ NSWOE } & \multicolumn{2}{|c|}{ SOC } & \multicolumn{2}{|l|}{$\mathbf{P}_{\mathbf{t}}$} \\
\hline & & $M S$ & $p$ & $M S$ & $p$ & $M S$ & $p$ & $M S$ & $p$ & $M S$ & $p$ & $M S$ & $p$ & $M S$ & $p$ & $M S$ & $p$ \\
\hline LS & 2 & 0.864 & $\begin{array}{ll}4 & 0.08\end{array}$ & 0.802 & $p<0.001$ & 0.01 & 0.653 & 0.004 & 0.192 & 108.18 & 0.088 & 249.463 & 0.227 & 0.005 & 0.277 & 7.16 & 0.86 \\
\hline LUT & 2 & 0.114 & $4 \mid p<0.001$ & 0.802 & $p<0.001$ & 0.006 & 0.003 & 0.001 & $p<0.001$ & 98.383 & $p<0.001$ & 2130.07 & $p<0.001$ & 0.255 & $p<0.001$ & 159.42 & 0.01 \\
\hline SD & 1 & 0.074 & $4 \mid p<0.001$ & 0.022 & 0.636 & 0.002 & 0.16 & 0.658 & $p<0.001$ & 38.845 & 0.331 & 4574.24 & $p<0.001$ & 0.012 & 0.001 & 104.89 & 0.04 \\
\hline LS*LUT & 4 & 0.064 & $\begin{array}{ll}4 & 0.123\end{array}$ & 0.121 & 0.314 & 0.002 & 0.168 & 0.002 & 0.492 & 17.17 & 0.787 & 196.57 & 0.32 & 0.004 & 0.359 & 92.03 & 0.12 \\
\hline $\mathrm{LS} * \mathrm{SD}$ & 2 & 0.002 & $\begin{array}{ll}2 & 0.93\end{array}$ & \begin{tabular}{|l}
0.01 \\
\end{tabular} & 0.998 & 0.005 & 0.974 & 0.02 & 0.395 & 19.654 & 0.616 & 46.796 & 0.76 & 0.001 & 0.883 & 3.25 & 0.93 \\
\hline LUT*SD & 2 & 0.065 & $5 \mid p<0.001$ & 0.022 & 0.797 & 0.002 & 0.174 & 0.001 & $p<0.001$ & 76.334 & 0.164 & 149.85 & 0.404 & 0.002 & 0.62 & 90.58 & 0.16 \\
\hline LS*LUT*SD & 4 & 0.31 & 0.441 & 0.355 & 0.014 & 0.001 & 0.294 & 0.001 & 0.672 & 17.054 & 0.789 & 287.074 & 0.154 & 0.002 & 0.709 & 45.06 & 0.44 \\
\hline ERROR & 36 & 0.033 & & 0.355 & & 0.001 & & 0.002 & & 40.074 & & 161.209 & & 0.003 & & 46.59 & \\
\hline TOTAL & 54 & & & & & & & & & & & & & & & & \\
\hline
\end{tabular}

LS = slope category (upper slope (30-60\%), middle slope (15-30\%) and lower slope (2-15\%), LUT = land use types (CTAFL, CVTCL and ECL), $\mathrm{SD}=$ soil depth $(0-20 \mathrm{~cm}, 20-40 \mathrm{~cm}), \mathrm{BD}=$ bulk density $\left(\mathrm{g} \mathrm{cm}^{-3}\right), \mathrm{MS}=$ mean square and $\mathrm{p}=\mathrm{p}$-value 